\title{
Herbal Medicines for the Management of Diabetic Mellitus in Ethiopia and Eretria including their Phytochemical Constituents
}

\author{
Asfaw Meresa*, Worku Gemechu, Hirut Basha, Netsanet Fekadu, Firehiwot Teka, Rekik Ashebir and \\ Ashenif Tadele
}

Directorate of Traditional and Modern Medicine Research, Ethiopian Public Health Institute, Addis Ababa, Ethiopia

Date of Receipt- 31/o3/2017
Date of Revision- 15/04/2017

Date of Acceptance- 23/04/2017

\begin{abstract}
Background: Diabetes mellitus (DM) is a serious metabolic disorder which causes blood glucose to rise in blood streams abnormally emanating from the difficulty in insulin secretion, its action or the two. The absence of effective modern treatments, the lifelong treatment with modern medicine their associated health side effects and their expensive prices etc. are among the challenging existing realities which devastate/worsen the health and economic burdens of the disease, especially in developing nations. In light of these, the search for cheaper, safe and potential drugs from medicinal plants is very crucial.
\end{abstract}

Objective: The aim of this review is to document existing information on Ethiopian and Eretrian medicinal plants used to treat DM from various sources.

The following documents (published scientific papers, MSc thesis, books and research reports on ethno-botany as well as different on-line sources) using the search words, diabetics, medicinal plants and ethno botanical studies, are used in order to compile this review article.

One hundred five plant species claiming to have anti-diabetic activity were reported in this study. Moringa stenoptela, Allium sativum, Caylusea abyssinica, Ajuga remota, Calpurnia aurea, and Psidium guajava are among them which are the most frequently mentioned medicinal plant species. Only few numbers of medicinal plants were scientifically evaluated for their anti-diabetic effects in animal models in the countries, whereas the majority of them are not yet evaluated. Next to leaf, root is the second most frequently employed part in the anti-diabetic herbal preparations.

Conclusion: The prevalence of diabetes mellitus carries on escalating all over the World and no effective treatments that can manage diabetes have ever been discovered till present. Medication with commercial oral hypoglycemic drugs is getting very difficult due their expensive costs and associated adverse side effects on the health of the patient. Hence, the search for effective and safe drugs from the available medicinal plants should be consolidated in order to alleviate the above mentioned problems. Moreover, the indigenous knowledge of medicinal plants has to be documented in order to initiate or motivate interested researchers to find out anti-diabetic promising candidate drug from folk medicine that might cure or manage the cases and enable self-reliance in the future.

Keywords: Diabetics, Prevalence, Medicinal plants, Ethnobotany, Phytoconstituents, Efficacy, Safety. 


\begin{tabular}{l} 
Address for \\
Correspondence \\
Directorate of Traditional and \\
Modern Medicine Research, \\
Ethiopian Public Health Institute, \\
P.O Box 1242, Addis Ababa, \\
Ethiopia \\
E-mail: \\
asfawmeresa03@gmail.com \\
\hline
\end{tabular}

\section{INTRODUCTION}

Diabetes mellitus (DM) is a common endocrine disorder characterized by hyperglycemia manifesting often with symptoms and signs of osmotic diuresis such as polyuria, polydypsia, calorie loss, generalized weakness, polyphagia and weight loss resulting from either an absolute deficiency (Type 1) or a relative deficiency (Type 2) of the hormone, Insulin ${ }^{1,2}$. Type 1 diabetes which formerly known as insulin dependent DM which usually occurred in childhood or in early adult age is caused by $\beta$-cell destruction, with absolute deficiency in insulin which is multifactorial causes such as genetic predisposition resulting from an autoimmune reaction to proteins of the islets cells of the pancreas. The other type of DM is Type 2 diabetes, also referred to as non- insulin dependent DM usually occur in people $>40$ years of age occurs with intact beta islet cell but there is peripheral tissue resistance to insulin ${ }^{1,2}$. These disorders associated with reversible and acute complication such as ketoacidosis become fatal if treatment is delayed ${ }^{3}$.

Disabling chronic complication affecting vision, kidneys, the nerves, blood vessels and heart are common in those who diagnosed very late or those who are in improper medical follow up or care $^{4}$. Even though the exact cause of this disorder is not clearly known yet there are common factors that contribute to the on-set diabetes. This factor is called predisposing or risk factors. Environmental factors such as diet, overweight or obesity and physical inactivity and genetic predisposition such as familial aggregation are among common mentioned risks particularly for the rise of type $2 \mathrm{DM}^{4-6}$.

Diabetes also puts people at a much higher risk of developing cardiovascular problems such as atherosclerotic cardiovascular disease (ASCVD) myocardial infarction (MI), stable or unstable angina, coronary or other arterial revascularization, stroke, transient ischemic attack, or peripheral arterial disease presumed to be of atherosclerotic origin which is the leading cause of morbidity and mortality among individuals with diabetes and is the largest contributor to the direct and indirect costs of diabetes. The common conditions coexisting with type 2 diabetes (e.g., hypertension and dyslipidemia) are clear risk factors for ASCVD, and diabetes itself confers independent risk ${ }^{6}$.

According to the World Health Organization (WHO) report, about 422 million adults were diabetic patients in 2014 globally, which increased by four times within three decade years who were only 108 million in 1980. This metabolic disorder is the cause of death for 1.5 million in 2012. Number of diabetic patients increased twice from $4.7 \%$ to $8.5 \%$ in adult population since1980. This is the results of increase in obesity which is one of the predisposing factors for the on-set of DM. Form the past ten years on ward diabetes prevalence increased largely in undeveloped and under developed countries compared to developed counties ${ }^{7}$.

Diabetes and its associated health problems are the main global heath burdens that challenge mankind globally despite discovery and utilization of hypoglycemic drugs to manage the case $^{8}$. Besides affecting the quality of life, the patients do not perform their daily usual business as they visit heath facilities so many times. This has decreased their income directly and created high economic loss of the country indirectly as it impedes the development of nation at large ${ }^{9}$. It is 
also expected to happen to be one of the major disablers and killers worldwide within the next 25 years $^{5}$. Managing DM has become a global problem in recent times due to the absence of successful treatments ${ }^{10}$. The currently existing therapies for diabetes which include insulin and the various oral hypoglycemic agents caused unnecessary side effects like hepatocellular injury; exacerbate renal diseases, lactic acidosis and diarrhea ${ }^{11}$.

\section{Epidemiology of Diabetics}

The prevalence and incidence of diabetes has been reported to vary among populations and among age groups of the same population. According to the IDF 2015 estimate, the world wide prevalence is 1 in 11 adults; more than 415 million of people have diabetes which will rise to 642 million in 2040. Among these Africa account a 14.2 million people with diabetes which is likely to increase 34.2 million in 2035and death of 5.0 million from diabetes in $2015^{6}$. In Ethiopia, the number of people aged 20-79 years living with diabetes was estimated to be 1.3 million adults with diabetes, and the prevalence was $2.9 \%{ }^{6}$. This figure is projected to reach 1.8 million by $2030^{12}$.

According to the recent community based study, the prevalence of diabetics in Ethiopia was $6 \%{ }^{13}$. Several risk contributing factors to type 2 diabetes include: family history of diabetes, the demographic and behavioral factors (age group, area of residence, alcohol consumption, adding salt to food, not engaged in vigorous physical activity, chewing chat) and biological risk factors (raised BP or currently on medication or impaired glucose tolerance (IGT)) were significantly associated $(p<0.001)$ with raised blood glucose, being overweight, history of gestational diabetes and poor nutrition during pregnancy to name a few $^{5,13,14}$.

\section{Adherence Challenge for the Management of Diabetics}

Different studies in the world have shown that adherence to diabetes treatment has been highly varied and may range from 1.4 to $88.0 \%{ }^{15-17}$. Low adherence to prescribed diabetes medications accounts for $30 \%$ to $50 \%$ of treatment failures, leading to worse treatment outcomes and which cause damages to vital organs. Treatment failure is in turn associated with reduced treatment benefits and can have a negative financial burden on both individual patients and the society at large ${ }^{18,19}$. Strictly follow-up the prescription of medical treatment by the patient becomes a challenge for the health care deliverer and scientific community. Hence a number of patients do not benefited from medical treatment resulting. This brings a profound negative effect on their quality of life and social impacts in many aspects ${ }^{20-23}$. In Ethiopia, the anti-diabetic medication adherence found to be 68.8 to 85 due to poor economic status, low education level and inadequate knowledge about the disease and its medication ${ }^{24-28}$.

\section{Herbal Medicines for the Management of DM} in Ethiopia

Diabetic mellitus prevalence rise globally and will expected to reach 642 million by 2040 . Lifestyle change, consume carbohydrate rich dish and overweight are the main factors contribute for the growth number of diabetic patient. From time to time the use of traditional medicine throughout world increases due to the locally availability, easily accessible, simple to use and assumed to be safe ${ }^{25-29}$. As in the other cases people from different parts of the world use herbal medicines to treat diabetes mellitus and its complications ${ }^{30}$. World health organization gives recognition for the treatment of herbal medicine for variable communicable and non-communicable chronic disease like $\mathrm{DM}^{31}$. The paradigm shift of diabetic treatments from conventional drugs to herbal medicine might be due to the belief that herbal medicines have low or no side effects and the fact that users feel that they able to control their choice of medication ${ }^{32}$. This review article aims to document the medicinal plants that have been used for the management of diabetic mellitus from the Ethiopian and Eritrean flora $^{33}$. It also covers the traditional uses, efficacy, safety and phyto-constituents of the anti-diabetic medicinal plants which have been evaluated scientifically.

TRADITIONAL USES, EFFICACY, SAFETY AND PHYTO CONSTITUTENTS STUDIES FOR MOST COMMONLY USED PLANTS

\section{Plant name: Stevia rebaudiana}

Family: Asteraceae

Local name: (not stated)

Part used: Leaf

Traditional uses: The product has been added to tea and coffee, cooked or baked goods, 
processed foods, beverages ${ }^{34}$ and used safely in herbal medicines, tonics, for diabetes and in the daily usage products like mouthwashes and toothpastes ${ }^{35}$. It can be used in chocolates and candies for diabetes and tooth decay ${ }^{35,36}$.

Efficacy data: A study showed that both the aqueous and $70 \%$ ethanolic leaf extracts of Stevia rebaudiana resulted in a fall in blood glucose level in alloxan-induced diabetic mice as a function of concentration. However, the aqueous extract showed a better reduction towards blood glucose level as compared with the ethanol extract ${ }^{37}$.

Safety and toxicity profile: Acute toxicity conducted on overnight fasted Swiss albino mice of both sexes for three consecutive days clearly showed that no significant changes in behaviors such as alertness, motor activity, breathing, restlessness, diarrhea, convulsions, coma and appearance of the animals as well as mortality were seen up to the maximum of $5000 \mathrm{mg} / \mathrm{kg}$ doses of both solvents' leaf extracts, indicating the non-toxic effect of plant extracts ${ }^{37}$.

Phytochemical constituents: The leaves contain diterpene glycosides (Figure 1) namely, stevioside, steviolbioside, rebaudioside A-F and ducloside A, which are responsible for the typical sweet taste ${ }^{38}$. Labdanediterpene (e.g. sterebins I-N), triterpenes, sterols and flavonoids are some of the non-sweet secondary metabolites that have also been identified from the leaves ${ }^{39}$. An experiment demonstrated that steviol glycosides possesses activities like antioxidant, mutagenic and bactericidal, antiviral, gastro protective, and their effectiveness on renal function, blood pressure and blood glucose ${ }^{40}$ (Figure 1).

Tesso and Konig $^{41}$ have also reported the phytochemical contents of $O$. integrifolia (Figure 2). From the dried leaves of the plant 40 constituents have been isolated by hydro-distillation. A class of terpenes such as monoterpenes, sesquiterpenes, diterpenes and their derivatives were reported to be present in the distillate. Trans-Sabinol [A], $\beta$-cyclocitral $[\mathrm{B}]$, dihydroedulan $[\mathrm{C}]$, theaspirane [D] and $(+)$-axinyssene [E] (prenylbisabolane diterpenes) were identified as the marker compounds. The prefuranic and furanic labdane diterpenoids, otostegindiol $[\mathrm{F}]$ and preotostegindiol $[\mathrm{G}]$ along with pentatriacontane and stigmasterol were also reported in the chloroform extract of the dried leaves of $O$. integrifolia ${ }^{41}$ (Figure 2).

Plant name: Ajuga remota Benth

Family: Lamiaceae

Local name: Akorarach (A)

Part used: Leaf

Traditional uses: In the Ethiopian traditional medicine, the fresh or dried leaves of $A$. remota was infused with water and sometimes with Alcohol, locally called "Arekie" and the infusions were used as remedy to heal diseases such as diabetes, malaria, pain and fevers, toothache, hypertension, stomachache, pneumonia etc ${ }^{42-44}$. Sometimes honey is added in to the preparation to make it palatable, since it has a bitter taste, and to store for longer periods for later use ${ }^{37}$.

Pharmacological activities: The plant was found to have most of the traditionally claimed activities including antiviral activity against Human Immunodeficiency Virus type 1, (HIV1) and Type 2 (HIV-2), antipyretic, antifeedant, antihypertensive, insecticidal, antifungal, antimalarial activities ${ }^{37}$.

Phytochemical constituents: Five different neo-clerodane diterpenes namely (Figure 3): Ajugarin I, II, III, IV and V and clerodin were isolated and characterized from the leaves of $A$. remota. Bioactive compounds namely ajugalactone, ergosterol-5, 8-endoperoxide and 8-O- acetylharpagide were also reported from this plant ${ }^{44-46}$ (Figure 3).

Efficacy profile: A study showed that both the aqueous and $70 \%$ ethanolic leaf extracts of the plant resulted in a fall in blood glucose level in alloxan-induced diabetic mice as a function of concentration. However, the aqueous extract showed a better reduction towards blood glucose level as compared with the ethanol extract ${ }^{37}$.

Safety and toxicity profile: Acute toxicity conducted on overnight fasted Swiss albino mice of both sexes foe three consecutive days clearly showed that no significant changes in behaviors such as alertness, motor activity, breathing, restlessness, diarrhea, convulsions, coma and appearance of the animals as well as mortality were seen up to the maximum of $5000 \mathrm{mg} / \mathrm{kg}$ doses of both solvents' leaf extracts, indicating the non-toxic effect of plant extracts ${ }^{47}$.

Plant name: Otostegia integrifolia Benth

Family: Lamiaceae 


\section{Local name: Tinjute [A]}

Part used: Leaf

Traditional uses: In Ethiopian folk medicine, the leaves of the stated medicinal plant have been utilized to diabetes mellitus by the community. As cited by a study, several studies also confirmed the uses of the various species of the genus Otostegia as having an ophthalmic, mosquito repellent, antimicrobial, anti-diabetic as well as antioxidant activities both in nature as well as scientifically ${ }^{48}$.

Phytochemical constituents: Results of the general phytochemical investigations reported the presence of phenolic compounds, saponins, reducing sugars and flavonoids but the lack of alkaloids, tannins and steroidal compounds in the $80 \%$ methanol leaf extract of this plant ${ }^{48}$. An investigation on the essential oil and chloroform extract of air-dried leaves gas chromatography (GC), GC-mass spectrometry (MS) and NMR techniques confirm the identification of many constituents belonging to the class of terpenes and their derivatives. The major component isolated includes (+)-1-methyl-4-(5, 9-dimethyl1-methylene-deca-4, 8-dienyl)-cyclohexene ${ }^{41}$.

Two labdane type diterpenoids, $(15,16$-epoxy3a, 9a-dihydroxy-labda-13(16) \& 14-diene and 9(13), 15(16) - diepoxy-3a-hydroxy-16dihydrolabda-14-ene] as well as saturated hydrocarbon called as pentatriacontane and stigmasterol were also isolated from the chloroform extract of the leaves (Tesso\&König, 2004). Isolation and structural elucidation of a prenylbisabolane type diterpene, $(+)$-axinyssene and two labdanediterpenes, otostegindiol, preotostegindiol and pentatriacontane from the air-dried leaves of the medicinal plant $O$. integrifolia Benth are reported (Figure 4) ${ }^{41}$.

Efficacy profile: An experiment has reported that $80 \%$ O.integrifolia leaf methanol crude extract reduces blood glucose level in normal and diabetic mice as well as in glucose induced hyperglycemic rats. As their study $200 \mathrm{mg} / \mathrm{kg}$ has shown maximum anti-diabetic, hypoglycemic and oral glucose tolerance activities in treated mice. Thus $200 \mathrm{mg} / \mathrm{kg}$ is the dose that lowered the high glucose level in streptozotocine-induced diabetic mice which is close to the normal range like the standard drug glibenclamide ${ }^{48}$.

Safety and toxicity profile: The methanolic leaf extract of the plant, up to the maximum dose of
$500 \mathrm{mg} / \mathrm{kg}$, resulted in no mortality or any adverse side effects up on the experimental animals ${ }^{48}$.

Plant name: Croton macrostachys

Family: Euphorbiaceae

Local name: Bisana [A]

Part used: Root

Traditional uses: Several ethno botanical studies done on different parts of Ethiopia have reported the medicinal uses of the plant for the management of malaria, skin diseases, urinary retention, intestinal parasites, hepatitis, amoebas and bronchitis ${ }^{49-51}$.

Phytochemical constituents: The general chemical screening tests on the hydro-ethanolic root extract Croton macrostachyus confirm the presence of alkaloids, phenolic compounds, tannins, terpenoids, saponins, phlobatannins and Flavonoids $^{52}$. A compound (Figure 5), named as crotepoxide was isolated and characterized from the $\mathrm{CH}_{3} \mathrm{Cl}$ extract of the berries of this plant using various chromatographic and spectroscopic techniques ${ }^{53}$.

Efficacy profile: According to a study, the hydro alcoholic root extract of $C$. macrostachys had shown a significant blood glucose lowering effect and improved glucose tolerance after administration of oral glucose solution. It is reported that the crude extract has maximum pharmacological effect at the dose of $300 \mathrm{mg} /$ $\mathrm{kg}$ and it is comparable with the standard drug glibenclamide ${ }^{52}$.

Safety and toxicity profile: Results of toxicity study on experimental mice for the first $24 \mathrm{hrs}$ as well as 14 consecutive days indicated that the root extract of Croton macrostachys did not result in mortality as well as Physical and behavioral signs on the test subjects at $2000 \mathrm{mg}$ and $5000 \mathrm{mg}$ doses of the extract per $\mathrm{kg}$ of B.W. This shows the plant extract is safe up to the maximum dose being administered ${ }^{52}$.

Plant name: Justicia schimperiana

Family: Acanthaceae

Local name: Sensel [A]

Part used: Leaf

Traditional uses: In Ethiopia, Justicia Schimperiana, belonging to the family acanthaceae, is locally utilized to heal ailments 
such as stomachache, burning, constipation, skin lesion, tooth ache and Scabies. The leaf macerate Justicia Schimperiana is claimed to have antidiabetic activity around Wolayta Sodo ${ }^{54}$.

Phytochemical constituents: Phytochemical analysis results confirmed the detection of secondary metabolites such as alkaloids, polyphenols, flavonoids, glycosides, phytosterols, saponins, triterpenes, and quinines as a major class of compounds ${ }^{55}$. Phytochemical analysis indicated the presence of saponins and alkaloids in chloroform, methanol and aqueous fractions of the leaf extract of J. schimperiana, while terpenoids were detected only in the chloroform fraction and flavonoids in methanol and aqueous fractions ${ }^{56}$.

Efficacy data: An investigation on the effect of the aqueous leaf extract of Justicia Schimperiana on normal and diabetic mice uncovered that the plant extract at two doses of [ $200 \mathrm{mg} / \mathrm{kg}$ and 400 $\mathrm{mg} / \mathrm{kg}$ ] post oral administration has shown a fall in blood glucose in all experimental models for the treatment periods ${ }^{54}$.

Toxicity profile: The median lethal concentration of the water leaf extract of the plant was concluded to be greater than $2000 \mathrm{mg} / \mathrm{kg}$ as no mortality or physical and behavioral signs up on the experimental rats were seen during the test periods ${ }^{54}$.

Plant name: Moringa stenopetala

Family: Moringaceae

Local name: Shiferaw [A]

Part used: Leaf

Traditional uses: The different parts of this medicinal plant have locally been utilized by the Ethiopian communities to manage diseases like malaria, hypertension, asthma, diabetes, stomach pain $^{57,58}$.

Pharmacological properties: Various literatures reported the uses of Moringastenopetala as anti-malarial, antileishmenial and antifertility ${ }^{59}$, hypotensive ${ }^{60}$, anti-hypertensive ${ }^{61}$, vasodilatory $^{61}$, hypoglycemic ${ }^{62}$, and anti-diabetic effects $^{58,63}$.

Efficacy data: An efficacy study illustrated that oral administration of the aqueous ethanol and n-butanol extracts of Moringastenopetala leaves $(500 \mathrm{mg} / \mathrm{kg}$ body weight) and metformin (150 $\mathrm{mg} / \mathrm{kg}$ ) significantly reduced blood glucose level
$(\mathrm{P}<0.05)$, improved serum lipid profiles, liver enzymes and kidney functions in diabetic rats after 14 days $^{63}$.

The effect of n-butanol fraction of ethanol leaf extract Moringa stenopetala, at $500 \mathrm{mg}$ oral dose administration per $\mathrm{kg}$ body weight, on blood glucose levels of alloxan induced diabetic mice were evaluated over a period of one month. The findings of this study revealed that a large decrease in BGL was recorded all rats treated with the fraction at third week treatment period and later. On the last day of the month, the butanol fraction treated groups showed a net reduction in BGL of $5.14 \%$ over those which received the standard drug, Glibenclamide. At the same time, the administration of butanol fraction caused Serum total cholesterol (TC) and triglyceride (TG) levels to decline a large extent.

A study also added that the ethanol and aqueous extracts as well as the various solvents' fractions of ethanol crude extracts and aqueous residue, each at $300 \mathrm{mg} / \mathrm{kg}$ single and repeated doses administration showed a huge fall in blood glucose level in both hypoglycemic and antihyperglycemic mice. All the above studies confirm the blood glucose lowering effect of moringa stenopetala leaves as well as the traditional claims.

Phytochemical constituents: Phytochemical screening tests on the crude aqueous leaf extracts and butanol fraction of Moringa stenopetala detect the presence of alkaloids, saponins, polyphenols, flavonoids, coumarins, terpenoids, anthraquinones, tannins, phytosterols and cardiac glycosides and the presence of all the secondary metabolites except saponins in $70 \%$ alcohol fractions ${ }^{58,64}$.

Rutin (Figure 6), which is the marker component, was isolated from the leaves of M. stenopetala leaves ${ }^{65}$.

The other four compounds (Figure 7) are isolated from acetone extract of root wood of Moringa stenopetala by subjecting the extract to column chromatographic separation. Based on the physical properties and spectroscopic (IR and NMR) data as well as literature reports, the chemical structures of the compounds were found to be cholest-5-en-3-ol, palmitic acid, n-octacosane and oleic acid, respectively. Three of the isolated compounds, namely cholest-5en-3-ol, palmitic acid and oleic acid pro- 
duced the highest activity against E.coli ${ }^{66}$ (Figure 7).

Three glycoside compounds were also detected in ethanol leaf extract and identified as rutin, 4-(4'-O-acetyl-rhamnosyloxy)benzyl isothiocyanate and 4-(4'-O-acetylrhamnosyloxy)-benzaldehyde. Two glycerides named as 1, 3"dilinoleoyl-2"olein and 1, 3"dioleoyl-2-linoleic were characterized from root extract of Moringastenopetala that showed good activity on aethiopica intracellular amastigotes ${ }^{67}$.

Toxicity: For this study, the test animals were orally given ascending concentrations (300, $2000,5000 \mathrm{mg} / \mathrm{kg}$ ) of the fraction and the result indicated that no detectable changes in behaviors such as alertness, motor activity, breathing, restlessness, diarrhea, convulsions, coma and appearance of the animals were observed. Similarly, no mortality was recorded at the above higher limit dose.

\section{Plant name: Vernonia amygdalina}

Family: Asteraceae

\section{Local name: Grawa [A]}

Part used: Leaf

Traditional uses: As compiled by a study, Vernonia Amygdalina, belonging to the Asteraceae family, is generally utilized for the management of various ailments including malaria schistomiasis, amoebic dysentery, headache, fever, venereal diseases, wounds, hepatitis, high blood pressure, hyperglycemia, and gastrointestinal problems. Furthermore, its leaf is eaten as vegetables to facilitate digestion besides washing vessels employed for the aim of fermentation ${ }^{68}$.

Phytochemical constituents: Preliminary screening of ethanolic extracts of both young and old $V$. amygdalina leaves revealed the presence of alkaloids, tannins, saponins, cardiac glycosides, terpenes, and steroids despite the absence and presence of flavonoids in the young and old leaves of the plant extract respectively ${ }^{69}$. A study showed that a large number of isolated bioactive compounds belonging to the various secondary metabolites have been obtained from the leaf part this plant by many investigators. Vernodalin (Sesquiterpene lactone), Epivernodalol (Sesquiterpene lactone), Vernomygdin (Ses- quiterpene lactone), Vernoniosides (Steroid Glucosides) and flavonoids such as luteolin, luteolin 7-O-glucosides, luteolin 7-O-glucuronide etc are among the compounds being isolated ${ }^{70}$.

Another study also confirmed that two compounds, named as epivernodalol and elemanolide, were isolated and characterized in the dichloromethane fraction of this medicinal plant $^{71}$. In an experiment, a compound called 3-amino-5-methylhex-5-enyl 3-amino-6methylhept-6-enyl terephthalate was isolated from the leaf of given medicinal plant ${ }^{68}$.

Efficacy data: The ethanolic extracts from both the old and young leaves of the given medicinal plant resulted a significant $(p<0.05)$ antihyperglycemic activity ${ }^{69}$.

Plant name: Aloe camperi

Family: Asphodelaceae

Local name: Ere [T]

Part used: Leaf

Traditional uses: The latex or leaf extract of Aloe camperi is traditionally utilized for the management skin burns, dandruff, stomach pain, hypertension, hair fall as well as diabetes by communities living in the Central and Southern Zones of Eritrea ${ }^{72,73}$.

Phytochemical constituents: A study reported that alkaloids, phenols, terpenoids, phenols, tannis saponins, flavonoids, glycosides, carbohydrate and proteins were contained in the methanol extract of the plant where as saponins steroids, terpenoids and coumarines were present in the hexane extract ${ }^{73}$.

Efficacy data: Studies have evaluated the antidiabetic activities of methanol leaf extracts of this medicinal plant by administering 200 and $400 \mathrm{mg} / \mathrm{kg}$ doses of the extract orally in diabetic induced experimental rats. The methanolic extract resulted in a dose-dependent lowering of FBG levels and the result exhibited very significant $(P<0.001)$ decreases in FBG level by the end of the experimental day as compared to the diabetic control. The extract at $400 \mathrm{mg} /$ $\mathrm{kg}$ concentration produced significant antihyperglycemic effect which is comparable to standard drug. An Oral glucose tolerance test (OGTT) on normal rats also indicated that the hyperglycemia with glucose challenge was significantly brought down $(P<0.001)$ by the 
plant extract at 60 and $120 \mathrm{~min}$ relative to the negative control ${ }^{74}$. The methanol leaf extract of Aloe camperi also showed a fall in blood glucose after oral administration of the extract in normal rats ${ }^{74}$. This might be attributed to the presence of hypoglycemic bioactive molecules like flavonoids, terpenoids, alkaloids or saponins contained within the leaf plant ${ }^{73}$.

Toxicity data: Acute toxicity test confirmed nontoxic nature of the methanolic leaf exact of this medicinal plant the median lethal concentration of exact is shown to be beyond $2000 \mathrm{mg} / \mathrm{kg}$ per body weight ${ }^{74}$.

\section{Plant name: Meriandra dianthera}

Family: Lamiaceae

Local name: Nehiba/Mezeguf (T)

Part used: Leaf

Traditional uses: $M$. dianthera has wider applications in the treatment of diabetes and other ailments in the traditional medical practices of the communities in the Central and Southern Zones of Eritrea ${ }^{72}$. An ethnobotanical study in Saharti samire, Southern part of Tigray, Ethiopia showed the uses of this plant for management of hypertension and diarrhea ${ }^{75}$.

Phytochemical constituents: A study by reported that phenols, terpenoids, phenols, tannins, saponins, glycosides, carbohydrate and proteins were contained in the methanol extract of the plant where as saponins steroids, terpenoids and coumarines were present in the hexane extract ${ }^{73}$.

Efficacy data: A study has evaluated the antidiabetic activities of methanol leaf extracts of this medicinal plant by administering 200 and $400 \mathrm{mg} / \mathrm{kg}$ doses of the extract orally in diabetic induced experimental rats. The methanolic extract resulted in a dose-dependent lowering of FBG levels and the result exhibited very significant $(P<0.001)$ decreases in FBG level by the end of the experimental day as compared to the diabetic control. The extract at $400 \mathrm{mg} /$ $\mathrm{kg}$ concentration produced significant antihyperglycemic effect which is comparable to standard drug. An Oral glucose tolerance test (OGTT) on normal rats also indicated that the hyperglycemia with glucose challenge was significantly brought down $(P<0.001)$ by the plant extract at 60 and $120 \mathrm{~min}$ relative to the negative control ${ }^{74}$. The methanol leaf extract of
Meriandra dianthera also showed a fall in blood glucose after oral administration of the extract in normal rats ${ }^{74}$. This might be attributed to the presence of hypoglycemic bioactive molecules like flavonoids, terpenoids, alkaloids or saponins contained within the leaf plant ${ }^{73}$.

Toxicity data: Acute toxicity test confirmed nontoxic nature of the methanolic leaf exact of this medicinal plant the median lethal concentration of exact is shown to be beyond $2000 \mathrm{mg} / \mathrm{kg}$ per body weight ${ }^{74}$.

Plant name: Pentas schimperiana (A. Rich) Vatke

\section{Family: Rubiaceae}

Local name: Woinagrefet

Part used: Leaf

Traditional uses: In Ethiopia, its fresh dry root bark powder mixed with water is taken orally for epilepsy ${ }^{51}$ and the of leaf decoction for management of diabetes mellitus ${ }^{76}$.

Phytochemical constituents: The results of general phytochemical analysis confirmed the detection of saponins, flavonoids, tannins, steroidal and phenolic compounds in the $80 \%$ methanolic leaf extract of the medicinal plant.

Efficacy profile: Both the hydro-methanolic fresh leaf extract as well as the hydro-methanolic and aqueous dried leaf extracts of $P$. schimperiana resulted in the reduction of blood glucose as a function of time and concentration in alloxaninduced diabetic mice. Similarly, the effect of oral administration of various solvent fractions of the plant on alloxan-induced diabetic mice each at a dose of $500 \mathrm{mg} / \mathrm{kg}$ also revealed that only the methanol and aqueous fractions caused a significant reduction blood glucose level where as the chloroform and acetone fractions did not $^{76}$.

Acute toxicity test: The study results demonstrated that the total aqueous and hydro alcoholic extracts of $P$. schimperiana resulted in no physical and behavioral signs such as restlessness, breathing, diarrhea etc. as well as caused no mortality up to $5000 \mathrm{mg} / \mathrm{kg}$ administered which also showed a median LD50 is above the tested dose ${ }^{76}$.

We used the following documents: published papers, MSc theses, books and research reports on ethno botany as well as different on-line sources in order to compile this review article ${ }^{77-108}$. 


\section{RESULTS}

Diabetes is a metabolic problem that contributes to major economic decline, there by hampering the growth of nations. Besides, unmanaged diabetes results in several chronic complications such as blindness, heart failure, and renal failure. In order to prevent this increasing health burdens, the development of research into new hypoglycemic and potentially anti-diabetic agents from plant origin is of great interest in recent times. Thus, this review article lists a total of one hundred five medicinal plants which are utilized for the management of diabetics in Ethiopia (Supplementary table 1).

$[\mathrm{A}]=$ Amharic, $[\mathrm{O}]=$ Affan Oromo, $[\mathrm{T}]=$ Tigrigna, $[\mathrm{Sm}]=$ Somaligna, $[\mathrm{Sd}]=$ Sidamigna

(Figure 8) shows the common plant part used were leaf followed by root.

Also, (Supplementary table 2) shows that Allium sativum, Cayluseaabyssinica, Calpurnia aurea, Moringastenoptela, Psidiumguajava and Thymus schimperiwere are the most commonly used medicinal plants for the management of diabetics in Ethiopia.

\section{CONCLUSION}

The prevalence of diabetes mellitus carries on escalating all over the World and no effective treatments that can manage diabetes have ever been discovered till the present. Medication with commercial oral hypoglycemic drugs is getting very difficult due their expensive costs and associated side effects on the health of the patient. Herbal medicines have recently been gaining increasing popularity by both developing and developed nations for the management of diseases, including diabetes. In this review, a total of one hundred five medicinal plants have been identified and documented for their use in management of diabetics. This article also presents the traditional medicinal uses, efficacy, toxicity as well as the bioactive compounds of some antidiabetic plants found in Ethiopia and Eretria.

Most of these medicinal plants are widely utilized in different parts of the country; only the safety and efficacy of Moringa stenopetala, Stevia rebaudiana, Pentas schimperiana, Meriandra dianthera, Vernonia Amygdalina, Justicia Schimperiana and Otostegia integrifolia were scientifically tested in animal models. As demonstrated by many scholars, the bioactive compounds contained within the plants have shown beneficial effects that can delay the onset of diabetic problems and adjust the metabolic disorders. Nevertheless, the pharmacological actions and chemistry of many of the medicinal plants have not been well studied scientifically. Therefore, further characterization of the active compounds, efficacy, evaluation of the mechanism of action and toxicity of the medicinal plants should be carried out. A research that can strengthen the documentation of the indigenous knowledge which contributes for the drug development and for self-reliance in the future is also recommended.

\section{COMPETING INTERESTS}

All authors declare that they have no competing interests.

\section{ACKNOWLEDGMENTS}

We greatly thank all authors who contribute a lot to the completion of this review.

\section{REFERENCES}

1. Ozougwu JC, Obimba KC, Belonwu CD, et $a l$. The pathogenesis and pathophysiology of Type 1 and Type 2 diabetes mellitus. J Physiol Pathophysiol. 2013;4(4):46-57.

2. Huang THW, Peng G, Kota BP, et al. Anti-diabetic action of Punica granatum flower extract: Activation of PPAR-c and identification of an active component. Toxicol App Pharmacol. 2005;207:160-9.

3. Kumar P, Clark M. Diabetes mellitus and other disorders of metabolism. In: Clinical Medicine (2nd edn). Elsevier, London. 2002;1069-71.

4. Kaku K. Pathophysiology of Type 2 diabetes and its treatment policy. JMAJ. 2010;53(1):41-6.

5. Deepashree BN, Prakash JA. Study on nutritional status of diabetics and associated risk factors. J Human Ecol. 2007;21:269-74.

6. http://www.idf.org/about-diabetes/risk-factors

7. http://apps.who.int/iris/bitstream/10665/2048 204871/1/9789241565257_eng.pdf

8. Burke JP, Williams K, Narayan KMV, et al. A population perspective on diabetes prevention: Whom should we target for preventing weight gain. Diabetes Care. 2003;26:1999-2004.

9. Mahabir D, Gulliford MC. Use of medicinal 
plants for diabetes in Trinidad and Tobago. Rev Panam Salud Publica. 1997;1:174-79.

10. Malviya N, Jain S, Malviya S. Antidiabetic potential of medicinal plants. Acta Pol Pharm Drug Res. 2010;67(2):113-8.

11. Rajalakshmi M, Eliza J, Priya CE, et al. Antidiabetic properties of Tinospora cordifolia stem extracts on streptozotocininduced diabetic rats. Afr J Pharm Pharmacol. 2009;3(5):171-80.

12. Wild S, Roglic G, Green A, et al. Global prevalence of diabetes: Estimates for the year 2000 and projections for 2030. Diabetes Care. 2004;27:1047-53.

13. Bekele A, Amenu K, Getachew $\mathrm{T}$, et al. Risk factors for chronic non-communicable diseases and prevalence of selected NCDs in Ethiopia special bulletin 18th Annual Review Meeting. 2016.

14. Abebe SM, Berhane Y, Worku A, et al. Diabetes mellitus in North West Ethiopia: A community based study. BMC Public Health. 2014;14:97.

15. Kalyango JN, Owino E, Nambuya AP. Nonadherence to diabetes treatment at Mulago Hospital in Uganda: prevalence and associated factors. Afr Health Sci. 2008;8(2):67-73.

16. Raum E, Kramer HU, Ruter G, et al. Medication non-adherence and poor glycaemic control in patients with Type 2 diabetes mellitus. Diabetes Res Clin Pract. 2012;97(3):377-84.

17. Sankar UV, Lipska K, Mini GK, et al. The adherence to medications in diabetic patients in rural Kerala. India. Asia Pac J Publ Health/ Asia-Pacific Academic Consortium for Public Health, Epub. 2013.

18. Wroth TH, Pathman DE. Primary medication adherence in a rural population: the role of the patient-physician relationship and satisfaction with care. J Am Board Fam Med. 2006;19(5):478-86.

19. DiMatteo MR, Giordani PJ, Lepper HS, et al. Patient adherence and medical treatment outcomes: A meta-analysis. Med Care. 2002;40(9):794-811.

20. Balkrishnan R, Rajagopalan R, Camacho FT, et al. Predictors of medication adherence and associated health care costs in an older population with Type 2 diabetes mellitus:
A longitudinal cohort study. Clin Ther. 2003;25(11):2958-71.

21. Kearney PM, Whelton M, Reynolds K, et al. Global burden of hypertension: Analysis of worldwide data. The Lancet. 2005;365:217-23.

22. Primatesta P, Poulter NR. Improvement in hypertension management in England: Results from the Health Survey for England 2003. J Hypertens. 2006;24(6):1187-92.

23. Hashmi SK, Afridi MB, Abbas K, et al. Factors associated with adherence to antihypertensive treatment in Pakistan. PLoS One. 2007;2(3):e280.

24. Abebaw M, Messele A, Hailu M, et al. Adherence and Associated Factors towards Antidiabetic Medication among Type II Diabetic Patients on Follow-Up at University of Gondar Hospital, Northwest Ethiopia. Advances in Nursing. 2016; 8579157.

25. Ayele, K, Tesfa, B, Abebe L, et al. Selfcare behavior among patients with diabetes in Harari, Eastern Ethiopia: the health belief model perspective. PloS One. 2012;7(4):e35515.

26. Wabe NT, Angamo MT, Hussein S. Medication adherence in diabetes mellitus and self-management practices among Type 2 diabetics in Ethiopia. N Am J Med Sci. 2011;3(9):418.

27. Kassahun A, Gashe F, Mulisa E, et al. Nonadherence and factors affecting adherence of diabetic patients to anti-diabetic medication in Assela General Hospital, Oromia Region, Ethiopia. J Pharm Bioallied Sci. 2016;8(2):124.

28. Teklay G, Hussien J, Tesfaye D. Nonadherence and associated factors among type 2 diabetic patients at Jimma University Specialized Hospital, Southwest Ethiopia. J Med Sci. 2013;13(7):578.

29. Modak M, Dixit P, Londhe J, et al. Indian herbs and herbal drugs used for the treatment of Diabetes. J Clin Biochem. 2007;40:163-73.

30. Ajaiyeoba EO, Ogbole OO, Ogundipe OO, et al. Ethnobotanical survey of plants used in the traditional management of viral infections in Ogun State of Nigeria. European J Sci Res. 
2006;13(1):64-73.

31. Bailey CJ, Day C. Traditional plant medicines as treatments for diabetes. Diabetes Care. 1989;12(8):553-64.

32. Marles R, Farnsworth NR. Plants as Sources of antidiabetic agents in: Economic and Medicinal Plant Research. Academic Press Limited, UK. 1994;6:149-87.

33. Johshi BS, Kaul PN. Alternative medicine: Herbal drugs and their critical appraisal- Part 1. Prog Drug Res. 2001;56:1-76.

34. Ahmed MB, Salahin M, Karim R, et al. An efficient method for in vitro clonal propagation of a newly introduced sweetener plant (Stevia rebaudianaBertoni.) in Bangladesh. American-Eurasian Journal of Scientific Research. 2007;2(2):121-5.

35. Sumida T. Studies on Stevia rebaudianaBertoni as a new possible crop for sweetening resource in Japan. Journal of the Central Agricultural Experimental Station. 1980;30:1-17.

36. Kassahun BM, Kebede W, Gebremeskel $\mathrm{H}$, et al. Performance of Stevia (Stevia rebaudianaBertoni) for morphological and economic traits under different ecologies of Ethiopia. Journal of Agricultural Development. 2012.

37. http://etd.aau.edu.et/bitstream/123456789/ 1563/2/Tadesse\%20Bekele.pdf

38. Mantovaneli ICC, Ferretti EC, Simões MR, et al. The effect of temperature and flow rate on the clarification of the aqueous steviaextract in a fixed-bed column with zeolites. Braz J Chem Eng. 2004;21:449-58.

39. McGarvey BD, Attygalle AB, Starratt AN, et al. New non-glycosidicditerpenes from the Leaves of Stevia rebaudiana. J Nat Prod. 2003;66:1395-98.

40. Madan S, Ahmad S, Singh GN, et al. Stevia rebaudiana (Bert.) Bertoni- A review. Ind J Nat Prod Resour. 2010;1:267-86.

41. Tesso H, Konig WA. Terpenes from Otostegiaintegrifolia. Phytochemistry. 2004;65(14):2057-62.

42. Coll J, Tandron Y. Isolation and Identification of neo-clerodanediterpenes from Ajugaremota by high performance liquid chromatography. Phytochemical Analysis. 2005;16:61-7.
43. Abebe D, Debella A, Urga K. Medicinal plants and other useful plants of Ethiopia. Food and Agriculture Organization of the United Nations. 2003.

44. Kuria KA, Chepkwony H, Govaerts C, et al. Antiplasmodial activity of isolates of Ajugaremota. J Nat Prod. 2002;65:789-93.

45. Kuria KA, De Coster S, Muriuki G, et al. Antimalarial activity of AjugaremotaBenth (Labiatae) and Caesalpiniavolkensii Harms (Caesalpiniaceae): in Vitro confirmation of ethnopharmacologicaluse.JEthnopharmacol. 2001;74:141-48.

46. Kariba RM. Antifungal activity of Ajugaremota. Fitoterapy. 2001;72:177-78.

47. Coll J. NMR shift data of neo-clerodanediterpenes from the genus Ajuga. Phytochemical Analysis. 2002;13:372-80.

48. Shewamene Z, Abdelwuhab M, Birhanu Z. Methanolic leaf exctract of OtostegiaintegrifoliaBenth reduces blood glucose levels in diabetic, glucose loaded and normal rodents. BMC Complement Altern Med. 2015;15(1):19.

49. Giday M, Teklehaymanot $\mathrm{T}$, Animut $\mathrm{A}$, et al. Medicinal plants of the shinasha, agew-awi and amhara peoples in Northwest Ethiopia. J Ethnopharmacol. 2007;110(3):516-25.

50. Yirga G. Use of traditional medicinal plants by indigenous people in Mekele town, capital city of Tigray regional state of Ethiopia. J Med Plants Res. 2010;4(17):1799-1800.

51. Mesfin F, Demissew S, Teklehaymanot T. An ethnobotanical study of medicinal plants in WonagoWoreda SNNPR, Ethiopia. J Ethnobiol Ethnomed. 2009;5:28.

52. http://www.wjpsonline.org/

53. Gelaw H, Adane L, Tariku Y, et al. Isolation of crotepoxide from berries of croton macrostachyus and evaluation of its anti-leishmanial activity. J Pharmacogn Phytochem. 2012;1(4).

54. Tesfaye A, Makonnen E, Gedamu S. Hypoglycemic and anti-hyperglycemic activity of aqueous extract of Justicia Schimperiana leaves in normal and streptozotocin-induced diabetic mice. IJPSR. 2016;7(2). 
55. AbebeH,HaileA.Phytochemicalinvestigation on leaf extract of Adhatodaschimperiana, Ethiopia. J Med Plants. 2014;2(2).

56. Abdela J, Shibeshi W. In vivo antimalarial activity of solvent fractions of the leaves of justiciaschimperianahochst ex nees against plasmodium berghei in mice. Ethiopian Pharmaceutical Journal. 2014;30(2):95-108.

57. http://www.jaicaf.or.jp/publications/ethiopia_ac.pdf

58. Sileshi T, Makonnen E, Debella A, et al. Antihyperglycemic and sub chronic toxicity study of Moringastenopetala leaves in mice. Journal of Coastal Life Medicine. 2014;2:214-21.

59. Mekonnen Y, Gessesse A. Documentation on the uses of Moringastenopetala and its possible antileishmanial and ant fertility effects. SINET: Ethiopian Journal of Science. 1998;21(2):287-95.

60. Mengistu M, Abebe Y, Mekonnen Y, et al. In vivo and in vitro hypotensive effect of aqueous extract of Moringastenopetala. African Health Sciences. 2012;12(4):545-51.

61. Geleta B, Makonnen E, Debella A, et al. In vitro vasodilatory activity of the Crude Extracts and Fractions of Moringastenopetala (Baker f.) Cufod leaves in isolated thoracic aorta of guinea pigs. Journal of Experimental Pharmacology. 2016;8:35-42.

62. Mussa A, Makonnen E, Urga K. Effects of the crude aqueous extract and isolated fraction of Moringastenopetala leaves in normal and diabetic mice. Pharmacology Online. 2008;3:1049-55.

63. Toma A, Makonnen E, Mekonnen Y, et al. Antidiabetic activities of aqueous ethanol and n-butanol fraction of Moringastenopetala leaves in streptozotocin induced diabetic rats. BMC Complement Altern Med. 2015;15(1): 242.

64. Geleta B, Makonnen E, Debella A, et al. In vivo antihypertensive and antihyperlipidemic effects of the crude extracts and fractions of moringastenopetala (baker f.) cufod leaves in rats. Front Pharmacol. 2016;7:97.

65. Habtemariam S, Varghese GK. Extractability of rutin in herbal tea preparations of Moringastenopetala leaves. Beverages.
2015;1(3):169-82.

66. Tesemma M,Adane L, Tariku Y, et al. Isolation of compounds from acetone extract of root wood of moringastenopetala and evaluation of their antibacterial activities. Research Journal of Medicinal Plants. 2013;7:32-47.

67. Bekele B. Isolation and characterization of compounds from Moringastenopetalaand evaluation of their antilishmanial activities. M.Sc. Thesis, Jimma University, Jimma, Ethiopia. 2011.

68. Werkneh AA. Isolation, structural elucidation, and bioactivity studies of leaf extract of VernoniaAmygdalina. American Journal of Applied Chemistry. 2015;3(1):14-20.

69. Asante DB, Effah-Yeboah E, Barnes P, et al. Antidiabetic effect of young and old ethanolic leaf extracts of vernoniaamygdalina: A comparative study. Journal of Diabetes Research. 2016.

70. Farombi EO, Owoeye O. Antioxidative and chemopreventive properties of Vernoniaamygdalina and Garciniabiflavonoid. Int J Environ Res Public Health. 2011;8(6):2533-55.

71. Owoeye O, Yousuf S, Akhtar MN, et al. Another anticancer elemanolide from vernoniaamygdalina del. Int $\mathrm{J}$ Biol Chem Sci. 2010;4:226-34.

72. The 5th National Report on the Implementation of the UNCBD. Department of Environment, Ministry of Land, Water and Environment, DEMLWE. 2014.

73. Mussie SD, Kareru PG, Keriko JM, et al. Ethnobotanical survey and preliminary phytochemical studies of plants traditionally used for diabetes in eritrea. European J Med Plants. 2015;9:1-11.

74. Mussie SD, Kareru PG, Kericko JM, et al. Evaluation of the anti-diabetic potential of the methanol extracts of Aloe camperi, Meriandradianthera and a polyherb. J Diabetes Mellitus. 2015;5:267-76.

75. Solomon A, Balcha A, Mirutse G. Study of plants traditionally used in public and animal health management in Seharti Samre district, Southern Tigray, Ethiopia. J Ethnobiol Ethnomed. 2015;11:22.

76. Dinku T, Tadesse S, Asres K. Antidiabetic activity of the leaf extracts of Pentasschimperiana Subsp. schimperiana (A. 
Rich) Vatke on Alloxan-Induced Diabetic Mice. Ethiop Pharm J. 2010;28:22-6.

77. Nardos A, Makonnen E, Debella A. Effects of crude extracts and fractions of Moringa stenopetala (Baker f) Cufodontis leaves in normoglycemic and alloxan-induced diabetic mice. Afr J Pharm Pharmacol. 2011;5(20):2220-25.

78. Enyew A, Asfaw Z, Kelbessa E, et al. Ethno botanical study of traditional medicinal plants in and around Fiche district, Central Ethiopia. Current Research Journal of Biological Sciences. 2014;6(4):154-67.

79. Kloos H, Menberu $\mathrm{T}$, Tadele $\mathrm{A}$, et al. Traditional medicines sold by vendors in Merkato, Addis Ababa: Aspects of their utilization, trade and changes between 1973 and 2014. Ethiop J Health Dev. 2014;28(2):1-17.

80. http://etd.aau.edu.et/bitstream/123456789/7794/

1/Askale\%20Gizaw\%20MSC\%20thesis\%20

2015.pdf

81. Mesfin K, Tekle G, Tesfay T. Ethnobotanical study of traditional medicinal plants used by indigenous people of Gemad District, Northern Ethiopia. Journal of Medicinal Plants Studies. 2013;1(4).

82. Limenih L, Umer S, Wolde-Mariam M. Ethnobotanical study on traditional medicinal plants in dega damot woreda, Amhara Region, North Ethiopia. IJRPC. 2015;5:258-73.

83. Aman BM. Metsehafe fewus (in amharic), Addis Ababa, Ethiopia. Eleni printing House Share Company. 2015;185-382.

84. Edilu A, Adane L, Woyessa D. Evaluation of antibacterial activities and phytochemical screening of the crude extracts of roots of caylusea abyssinica (Fresen.). MiddleEast Journal of Scientific Research. 2014;22(7):960-965.

85. Tamiru W, Engidawork E, Asres K. Evaluation of the effects of $80 \%$ methanolic leaf extract of Caylusea abyssinica (fresen.) fisch. \& Mey. On glucose handling in normal, glucose loaded and diabetic rodents. BMC Complement Altern Med. 12(1):1.

86. http://etd.aau.edu.et/bistream/123456789/5817/1/ Freshet $\% 20$ Assefa.pdf
87. Regassa R. Assessment of indigenous knowledge of medicinal plant practice and mode of service delivery in Hawassa city, Southern Ethiopia. J Med Plants Res. 2013;7(9):51735.

88. http://etd.aau.edu.et/bitstream/123456789/7563

/1/Amanuel\%20Godebo.pdf

89. http://etd.aau.edu.et/bitstream/123456789

\section{/244/3/SINTAYEHU\%20TAMENE\%20}

\section{BEYENE.pdf}

90. Amuamuta A, Na-Bangchang K. A review of ethnopharmacology of the commonly used antimalarial herbal agents for traditional medicine practice in Ethiopia. Afr J Pharm Pharmacol. 2015;9(25):615-27.

91. Yadav RH. Medicinal plants in folk medicine system of Ethiopia. Journal of Poisonous and Medicinal Plants Research. 2013;1(1):7-11.

92. Desta B. Ethiopian traditional herbal drugs. Part I: Studies on the toxicity and therapeutic activity of local taenicidal medications. J Ethnopharmacol. 1995;45(1):27-33

93. http://ethnomed.Org/clinical/pharmacy/ ethiopion-herb-drug-interactions

94. Suleman S, Alemu T. A survey on utilization of ethnomedicinal plants in Nekemte Town, East Wellega (Oromia), Ethiopia. J Herbs Spices Med Plants. 2012;18(1):34-57.

95. Nigussie Z, Alemayehu G. Sesbania sesban (L.) Merrill: Potential uses of an underutilized multipurpose tree in Ethiopia. Afr J Plant Sci. 2013;7(10):468-75.

96. Wolde $\mathrm{T}$, Engidawork E, Asres $\mathrm{K}$, et al. Evaluation of hepatoprotective activities of Satureja punctata Benth Briq and Solanecio angulatus Vahl Jeffrey in ferric nitrillotriacetate induced hepatotoxicity in rats. Pharm J. 2010;28:63-74.

97. http://etd.aau.edu.et/bitstream/123456789/381/3/ GETANEH\%20GEBEYEHU.pdf

98. Megersa M. Ethnobotanical study of medicinal plants in Wayu Tuka Wereda, East Wollega zone of Oromia region, Ethiopia. MSc Thesis, Addis Ababa University. 2010. 
99. Sintayehu B, Asres K, Raghavendra Y. Radical scavenging activities of the leaf extracts and a flavonoid glycoside isolated from Cineraria abyssinica Sch. Bip. Exa. Rich. Journal of Applied Pharmaceutical Science. 2012;2(4):44.

100. Issa IA, Bule MH. A comparative study of the hypoglycemic effect of aqueous and methanolic extracts of myrtus communis on alloxan induced diabetic siwis albino mice. Med Aromat Plants. 2015;4(190):2167-412.

101. Waheed A, Miana GA, Ahmad SI. Clinical investigation of hypoglycemic effect of leaves of mangifera inidca in type2 (NIDDM) diabetes mellitus. Pakistan Journal of Pharmacology. 2006;23:13-18.

102. Getenet C. An ethnobotanical study of plants used in traditional medicine and as wild foods in and around tara gedam and amba remnant forests in libo kemkem wereda, south Gonder zone, Amhara region, Ethiopia. Addis Ababa University, Ethiopia. 2011.

103. Sibhat GG. Preliminary phytochemical screening and blood glucose lowering activity of methanol extract of salvia tilifolia vahl aerial part. Int J Pharm Biol Sci Arch. 2015;5(5).

104. Keshebo D, Choundhury MK, Dekebo AH. Investigation on toxicity, hypoglycemic effect of the root bark of Securidacam longepedunculata Fresen (Polygalaceae) and determination of heavy metals in it. Annals Biol Res. 2014;5(6):15-9.

105. Hassan-Abdallah A, Merito A, Hassan S, et al. Medicinal plants and their uses by the people in the Region of Randa, Djibouti. J Ethnopharmacol. 2014;148(2):701-13.

106. Kebede A, Ayalew S, Mesfin A, et al. Ethnobotanical investigation of traditional medicinal plants commercialized in the markets of Dire Dawa city, eastern Ethiopia. Journal of Medicinal Plants. 2016;4(3):170-78.

107. Mulata HN, Gnanasekaran N, Melaku $\mathrm{U}$, et al. Phytochemical screening and assessment of in vitro antioxidant activities of Calpurnia aurea seeds and leaves. IJPPR. 2015;2(2):1-12.

108. http://care.diabetesjournals.org/content/39/ Supplement_1/S60 
Table 1. List of medicinal plants used to manage diabetes mellitus

\begin{tabular}{|c|c|c|c|c|c|c|c|}
\hline $\begin{array}{l}\text { S. } \\
\text { No }\end{array}$ & Scientific name & Family & Local name & Parts used & Method of preparation & Other Medicinal Uses & Reference \\
\hline 1. & Aloe pulcherrima $G$ & Xanthorrhoeaceae & Set-eret (A) & Latex & $\begin{array}{l}\text { water and sugar boiled } \\
\text { together and given } \\
\text { orally }\end{array}$ & Asthma, diabetes dandruff & [79] \\
\hline 2. & $\begin{array}{l}\text { Thymus schimperi } \\
\text { Ronniger, }\end{array}$ & Lamiaceae, & Tosign (A) & $\begin{array}{l}\text { Stem, leaf, } \\
\text { Whole plant }\end{array}$ & $\begin{array}{l}\text { Dried stem and leaf } \\
\text { powder boiled with tea } \\
\text { is given orally }\end{array}$ & Diabetes & {$[80,79]$} \\
\hline 3. & Croton macrostachys & Euphorbiaceae & Bisana (A) & Root & & $\begin{array}{l}\text { Anti diabetic activity, } \\
\text { malaria, purgative and anti- } \\
\text { inflammatory effects, }\end{array}$ & {$[52,81]$} \\
\hline 4. & Aloe vera & Asphodelaceae & Eret (A) & Fresh leaf & Not specified & Diabetes & [82] \\
\hline 5. & Euphorbia sp. Gmel & Euphorbiaceae & Kulkual (A) & Latex & $\begin{array}{l}\text { The plant is cut and } \\
\text { squeezed until enough } \\
\text { is collected, a cup and } \\
\text { half is drunk three times } \\
\text { a day before food }\end{array}$ & $\begin{array}{l}\text { Diabetes, Homorroids, } \\
\text { ascaries }\end{array}$ & {$[83]$} \\
\hline 6. & $\begin{array}{l}\text { Asparagus africanus } \\
\text { Lam }\end{array}$ & Asparagaceae & $\begin{array}{l}\text { Sereti (A)Sarritt/ } \\
\text { qastanticha }\end{array}$ & Root, Leaf & $\begin{array}{l}\text { Give the dikus with } \\
\text { food and drinks } \\
\text { Powdered and taken } \\
\text { orally }\end{array}$ & $\begin{array}{l}\text { Diabetes, nekersa, urine } \\
\text { retention, chest pain, } \\
\text { sleeping, Snake bite, } \\
\text { poisoning, diabetes }\end{array}$ & {$[79,84]$} \\
\hline 7. & $\begin{array}{l}\text { Discopodium } \\
\text { penninervum Hoschst }\end{array}$ & Solanceae & Ameraro (A) & Leaf & $\begin{array}{l}\text { Eat the boiled leaf as a } \\
\text { cabbage }\end{array}$ & Diabetes & {$[84]$} \\
\hline 8. & $\begin{array}{l}\text { Caylusea absyssinica } \\
\text { (fresen) }\end{array}$ & Resedaceae & Rench (A) & Leaves & Not specified & $\begin{array}{l}\text { stomachache, skin } \\
\text { diseases, diabetes mellitus } \\
\text { and amoeba }\end{array}$ & $\begin{array}{l}{[43,} \\
85-87]\end{array}$ \\
\hline 9. & $\begin{array}{l}\text { Ajuga integrifolia Ham- } \\
\text { Buch. Labiatae }\end{array}$ & lamiaceae & $\begin{array}{l}\text { Harmagusa[O] } \\
\text { Akorarach (A) }\end{array}$ & Leaves, Root & $\begin{array}{l}\text { Aqueous and sometimes } \\
\text { "Arekie" (alcohol) } \\
\text { infusion of the fresh or } \\
\text { dried leaves }\end{array}$ & $\begin{array}{l}\text { Malaria, toothache, skin } \\
\text { disease whooping cough, } \\
\text { pneumonia,hypertension, } \\
\text { diabetes etc... }\end{array}$ & $\begin{array}{l}{[37,43,} \\
84,87]\end{array}$ \\
\hline 10. & $\begin{array}{l}\text { Solanum marginatum } \\
\text { L.f }\end{array}$ & Solanaceae & $\begin{array}{l}\text { Zerch embuay, } \\
\text { (A) }\end{array}$ & seeds & $\begin{array}{l}\text { Seeds taken out } \\
\text {,washed, dried and } \\
\text { drunk with goats kebe } \\
\text { or milk after boiling }\end{array}$ & $\begin{array}{l}\text { Cough, lung problem, } \\
\text { diabetes }\end{array}$ & {$[84]$} \\
\hline 11. & Podocarpus gracilis & Podocarpaceae & Zigba (A) & $\begin{array}{l}\text { Gum and } \\
\text { shoot }\end{array}$ & $\begin{array}{l}\text { Betazma mar lewuso } \\
\text { meblat( } 1 / 2 \text { spoon })\end{array}$ & $\begin{array}{l}\text { Cough, lung problem, } \\
\text { diabetes, }\end{array}$ & {$[43,84]$} \\
\hline 12. & $\begin{array}{l}\text { Crinum } \\
\text { abyssinicum(Hochst) ex } \\
\text { A. Rich }\end{array}$ & (Amaryllidaceae) & $\begin{array}{l}\text { Yejib shinkutrt } \\
\text { (A) }\end{array}$ & $\begin{array}{l}\text { Shoot tip- } \\
\text { fresh }\end{array}$ & $\begin{array}{l}\text { Squeezed, mixed with } \\
\text { water, drink }\end{array}$ & Hypertension, diabetes & {$[88]$} \\
\hline 13. & Psidium guajava & Myrtaceae & Zeytun (A) & Leaves & $\begin{array}{l}\text { Boil with the leaves } \\
\text { of camellia sinesis and } \\
\text { drink }\end{array}$ & $\begin{array}{l}\text { Wounds, ulcers, } \\
\text { bronchitis,hypoglycemic, } \\
\text { anti hyperglycemic, anti- } \\
\text { inflammatory effect etc.. }\end{array}$ & $\begin{array}{l}{[73,88,} \\
89]\end{array}$ \\
\hline 14. & $\begin{array}{l}\text { FoeniculumVulgare } \\
\text { Miller. }\end{array}$ & Apiaceae & Ensilsl (A) & Fresh leaves & Boil and drink & $\begin{array}{l}\text { Hypertension, diabetes, } \\
\text { gonorrhea }\end{array}$ & {$[88]$} \\
\hline 15. & Argemone thiopia.L & papaveraceae & Wajo uta $(\mathrm{Sd})$ & leaves & $\begin{array}{l}\text { Dry or fresh leaves } \\
\text { crushed, pounded, and } \\
\text { filtered then infusion } \\
\text { drunk in the middle of } \\
\text { night }\end{array}$ & Diabetes & {$[90]$} \\
\hline 16. & $\begin{array}{l}\text { Delonix regia (Boj.ex } \\
\text { Hook) }\end{array}$ & Fabaceae & $\operatorname{Mimi}(\mathrm{Sd})$ & leaves & $\begin{array}{l}\text { Dry or fresh leaves } \\
\text { crushed, pounded, and } \\
\text { filtered then infusion } \\
\text { drunk in the middle of } \\
\text { night }\end{array}$ & Diabetes & {$[90]$} \\
\hline 17. & Moringa-stenoptela & Moringaceae & Shiferaw (A) & Fresh leaves & $\begin{array}{l}\text { Fresh leaves cooked as } \\
\text { food and eaten or Boil } \\
\text { and drink its soup }\end{array}$ & $\begin{array}{l}\text { Hyperglycemia, kidney } \\
\text { infection, cold, malaria }\end{array}$ & $\begin{array}{l}{[58,87,88,} \\
90-92]\end{array}$ \\
\hline 18. & Calpurnia aurea & Fabaceae & Digita (A) & Leaf & Not specified & $\begin{array}{l}\text { Malaria, diarrhea, diabetes, } \\
\text { rabies, hypertension } \\
\text { amoebiasis, giardiasis etc }\end{array}$ & $\begin{array}{l}{[49,93,} \\
111]\end{array}$ \\
\hline 19. & Lens culinaris Medik & Fabaceae & Misir [A] & seed & Not specified & Diabetes & [49] \\
\hline 20. & $\begin{array}{l}\text { Acacia nilotica (L.) } \\
\text { seed, stem bark }\end{array}$ & Fabaceae & Ghered (T) & $\begin{array}{l}\text { seed, stem } \\
\text { bark }\end{array}$ & $\begin{array}{l}\text { Decoction of the seed } \\
\text { or bark is used or } \\
\text { Regularly fruits are } \\
\text { given in spoonful before } \\
\text { break fast }\end{array}$ & $\begin{array}{l}\text { Malaria, cough, dysentery, } \\
\text { insect repellent Diabetes, } \\
\text { diarrhea, hemorrhage, tooth }\end{array}$ & {$[73,94]$} \\
\hline
\end{tabular}




\begin{tabular}{|c|c|c|c|c|c|c|c|}
\hline 21. & Ambrosia maritma $L$ & Asteraceae & & Whole plant & Not specified & $\begin{array}{l}\text { Reheumatic pains, asthma, } \\
\text { biliharziasis, diabetes and } \\
\text { to expel renal stones }\end{array}$ & [94] \\
\hline 22. & Bryonia cretica $L$. & Cucurbitaceae & & Not specified & Not specified & $\begin{array}{l}\text { Bitter tonic, ameliorate } \\
\text { the condition of diabetic } \\
\text { persons, whooping cough, } \\
\text { bronchitis and tonsillitis }\end{array}$ & [94] \\
\hline 23. & $\begin{array}{l}\text { Centaurium pulchelum } \\
\text { (Swartz) druce }\end{array}$ & Gentiaceae & & & $\begin{array}{l}\text { Infusion of the herb is } \\
\text { used for diabetes }\end{array}$ & $\begin{array}{l}\text { Gastric and abdominal } \\
\text { pain, diabetes, } \\
\text { hypertension, renal colic, } \\
\text { rheumatic pains etc... }\end{array}$ & [94] \\
\hline 24. & $\begin{array}{l}\text { Cleome droserifolia } \\
\text { (Forssk)Delile }\end{array}$ & Cleomaceae & & & $\begin{array}{l}5 \mathrm{gm} \text { of paste powder } \\
\text { is topically used before } \\
\text { meal for treatment }\end{array}$ & $\begin{array}{l}\text { Hyperglycemia (diabetes), } \\
\text { wounds and for dermatitis }\end{array}$ & [94] \\
\hline 25. & Glinus lotoides & Molluginaceae & & Fruit & Not specified & Anti-diabetic & [95] \\
\hline 26. & $\begin{array}{l}\text { Stevia rebaudiana } \\
\text { Bertoni }\end{array}$ & Asteraceae & & Leaf & Aqueous leaf extract & $\begin{array}{l}\text { diabetes, hypertension, } \\
\text { antimicrobial, anti obesity } \\
\text { and antioxidant activities }\end{array}$ & [37] \\
\hline 27. & $\begin{array}{l}\text { Aloe camperi } \\
\text { Schweinfurth }\end{array}$ & Aloaceae & Sandai-ere $(\mathrm{T})$ & $\begin{array}{l}\text { fresh leaves, } \\
\text { latex }\end{array}$ & $\begin{array}{l}\text { Extract of the latex or } \\
\text { leaf is used regularly }\end{array}$ & $\begin{array}{l}\text { Skin burns, dandruff, } \\
\text { stomach pain, hypertension, } \\
\text { hair fall }\end{array}$ & {$[73,74]$} \\
\hline 28. & $\begin{array}{l}\text { Meriandra dianthera } \\
\text { (Roth) Briq. }\end{array}$ & Lamiaceae & $\begin{array}{l}\text { Nehiba/Mezeguf } \\
\text { (T) }\end{array}$ & fresh leaves & $\begin{array}{l}\text { Extract of the leaf is } \\
\text { taken } 1 \text { cup daily }\end{array}$ & $\begin{array}{l}\text { Hypertension, diarrhea, } \\
\text { diabetic gastritis, bronchial } \\
\text { asthma, purgative, diarrhea, }\end{array}$ & {$[73,75]$} \\
\hline 29. & $\begin{array}{l}\text { Otostegia integrifolia } \\
\text { Benth. }\end{array}$ & Lamiaceae & Ch'endog $(\mathrm{T})$ & Leaf & $\begin{array}{l}\text { Extract of the leaves } \\
\text { taken in the evening }\end{array}$ & $\begin{array}{l}\text { Gynecological problems, } \\
\text { inflammation, insecticidal, } \\
\text { antioxidant, anti diabetic } \\
\text { activity, etc... }\end{array}$ & {$[48,73]$} \\
\hline 30. & $\begin{array}{l}\text { Pentas schimperiana } \\
\text { Subsp. }\end{array}$ & & Woina grefet & Leaves & decoctions of leaves & diabetes, epilepsy & {$[76]$} \\
\hline 31. & Allium sativum & Lilliceae & $\begin{array}{l}\text { Shiguerti-tsada } \\
\text { (T) }\end{array}$ & bulb & $\begin{array}{l}\text { Fresh bulb is eaten } \\
\text { raw or added in sauce } \\
\text { The powdered bulb is } \\
\text { dispersed in decocted } \\
\text { root. }\end{array}$ & $\begin{array}{l}\text { Asthma, antiseptic, } \\
\text { diuretic, hypertension, } \\
\text { expectorant }\end{array}$ & $\begin{array}{l}{[73,87,} \\
93,96,97]\end{array}$ \\
\hline 32. & Sesbania sesban $(L)$ & Papilionoideae, & girangire (A) & $\begin{array}{l}\text { Seeds and } \\
\text { leaves }\end{array}$ & Not specified & $\begin{array}{l}\text { Anti-diabetic, antioxidant } \\
\text { effect, antimicrobial } \\
\text { activity, anti fertility agent, } \\
\text { ethno veterinary use }\end{array}$ & [98] \\
\hline 33. & $\begin{array}{l}\text { Satureja punctata } \\
\text { Benth. Briq }\end{array}$ & Lamiaceae) & Lomishet (A) & leaves & $\begin{array}{l}\text { leaves are cooked and } \\
\text { the extract drank }\end{array}$ & $\begin{array}{l}\text { treatment of liver diseases, } \\
\text { hypertension, diabetes and } \\
\text { other disorders }\end{array}$ & [99] \\
\hline 34. & Datura stramonium L. & Solonaceae & Asangra $(\mathrm{O})$ & Root & $\begin{array}{l}\text { The root is decocted } \\
\text { overnight and mixed } \\
\text { with rancid butter }\end{array}$ & $\begin{array}{l}\text { Toothache, asthma, } \\
\text { hypertension, diabetes } \\
\text { mellitus }\end{array}$ & [97] \\
\hline 35. & $\begin{array}{l}\text { Lagenaria abyssinica } \\
\text { (hook.f.) C.Jeffrey }\end{array}$ & Cucurbitaceae & Buqe setena $(\mathrm{O})$ & Flower & $\begin{array}{l}\text { The powdered flower is } \\
\text { dispersed in water }\end{array}$ & Diabetic Mellitus, rabies & [97] \\
\hline 36. & Guizotia Schimperi & Asteraceae & Adey Abeba (A) & Whole part & $\begin{array}{l}\text { It is crushed with } \\
\text { whole part of Cucumis } \\
\text { ficifolius, boiled in the } \\
\text { water and one glass } \\
\text { is taken orally until } \\
\text { recovery. }\end{array}$ & Diabetes & {$[100]$} \\
\hline 37. & $\begin{array}{l}\text { Indigofera spicata } \\
\text { Forssk. }\end{array}$ & Fabaceae & Reencii (O) & leaves & $\begin{array}{l}\text { Leaves powdered and } \\
\text { mixed in water and } \\
\text { taken when need arises }\end{array}$ & Diabetes & {$[101]$} \\
\hline 38. & Cineraria abyssinica & Asteraceae) & ‘Esemefirh’(G) & $\begin{array}{l}\text { Leaves,aerial } \\
\text { parts }\end{array}$ & $\begin{array}{l}\text { The aqueous decoction } \\
\text { of the leaves and aerial } \\
\text { parts }\end{array}$ & $\begin{array}{l}\text { cancer, liver and kidney } \\
\text { diseases, hypertension, } \\
\text { diabetes }\end{array}$ & [102] \\
\hline 39. & Myrts commuis & Myrtaceae & Ades (A) & Leaves Fruit & Not specified & Anti-hyperglycemic & [103] \\
\hline 40. & Allium Сера & Alliaceae & Qey-shnkurt (A) & bulb & $\begin{array}{l}\text { Freshly cut bulb is often } \\
\text { used }\end{array}$ & $\begin{array}{l}\text { Hypoglycemic, anti- } \\
\text { hyperglycemic activity in } \\
\text { normal and STZ induced } \\
\text { diabetic rats etc... }\end{array}$ & {$[73,87]$} \\
\hline 41. & Curcuma longa & Zingeberaceae & Ird (A) & & Not specified & $\begin{array}{l}\text { Antihyperglycemic effect } \\
\text { in STZ induced diabetic } \\
\text { rats }\end{array}$ & [87] \\
\hline 42. & Coriandrum-sativum & Apiaceae & Dimbelal (A) & & Not specified & $\begin{array}{l}\text { Hypoglycemic effect in } \\
\text { normal rats }\end{array}$ & [87] \\
\hline
\end{tabular}




\begin{tabular}{|c|c|c|c|c|c|c|c|}
\hline 43. & Cuminum- сутіпит & Apaiaceae & Ensilal (A) & & Not specified & $\begin{array}{l}\text { Antidiabetic influence in } \\
\text { STZ induced Diabetic rats }\end{array}$ & [87] \\
\hline 44. & $\begin{array}{l}\text { Cymbopogon-thiopia } \\
\text { Stapf }\end{array}$ & Poaceae & Lomi sar (A) & & Not specified & $\begin{array}{l}\text { Hypoglycemic effect in } \\
\text { normal rats }\end{array}$ & [87] \\
\hline 45. & Linum- usitatissimum & Linaceae & Telba (A) & & Not specified & $\begin{array}{l}\text { Antihyperglycemic effect } \\
\text { in alloxan induced diabetic } \\
\text { rats }\end{array}$ & [87] \\
\hline 46. & Mangifera indica $L$. & Anacardiaceae & Mangus (T) & $\begin{array}{l}\text { leaf, stem } \\
\text { bark }\end{array}$ & $\begin{array}{l}\text { Decoction of leaf } \\
\text { or stem bark is used } \\
\text { regularly }\end{array}$ & $\begin{array}{l}\text { Diuretic, diarrhea, } \\
\text { dysentery, anemia, } \\
\text { bronchitis, hypertension }\end{array}$ & $\begin{array}{l}{[73,87,} \\
104]\end{array}$ \\
\hline 47. & Nigella sativa $L$. & Ranunculaceae & $\begin{array}{l}\text { Abosoda (T) } \\
\text { Tikur-Azmud (A) }\end{array}$ & Seed & $\begin{array}{l}\text { Seeds added in bread } \\
\text { or a spoon of powdered } \\
\text { seeds taken orally } \\
\text { before meal }\end{array}$ & $\begin{array}{l}\text { Anti-hyperglycemic } \\
\text { activity in diabetic rats, } \\
\text { asthma, dysentery, } \\
\text { hypertension, } \\
\text { gastrointestinal problems }\end{array}$ & {$[73,87]$} \\
\hline 48. & $\begin{array}{l}\text { Trigonella foenum- } \\
\text { graecum } L .\end{array}$ & Fabaceae & $\begin{array}{l}\text { Abe'ake (T) } \\
\text { Abish (A) }\end{array}$ & Seed & $\begin{array}{l}\text { Extract of the dried and } \\
\text { powered seed is used } \\
\text { regularly }\end{array}$ & $\begin{array}{l}\text { Diuretic, antipyretic, } \\
\text { stomachic, anemia, } \\
\text { hypertension, diabetes } \\
\text { gastrointestinal pains }\end{array}$ & {$[73,87]$} \\
\hline 49. & $\begin{array}{l}\text { Zingiber officinale } \\
\text { Roscoe }\end{array}$ & Zingiberaceae & Zingible (T) & Root & $\begin{array}{l}\text { Tea of the rhizome } \\
\text { frequently used }\end{array}$ & $\begin{array}{l}\text { Digestive disorders, } \\
\text { stimulant, bronchitis, throat } \\
\text { infections, hypoglycemia }\end{array}$ & {$[73,87]$} \\
\hline 50. & Solanum incanum L. & Solanaceae & Uengule $(\mathrm{T})$ & $\begin{array}{l}\text { Fruit } \\
\text { Root }\end{array}$ & $\begin{array}{l}\text { Fruits boiled in hot } \\
\text { water or mixed with } \\
\text { yogurt or root is chewed } \\
\text { and swallowed. }\end{array}$ & $\begin{array}{l}\text { Expectorant, diabetes } \\
\text { stomach ache, fever, snake } \\
\text { bite, bronchitis. }\end{array}$ & {$[73,105]$} \\
\hline 51. & Salvia lavandulifolia & Lamiaceae & & & Not specified & Hypoglycemic activity & {$[106]$} \\
\hline 52. & Salvia officinalis & Lamiaceae & & & Not specified & Hypoglycemic activity & {$[106]$} \\
\hline 53. & Salvia fruticosa Mill & Lamiaceae & & & Not specified & Hypoglycemic activity & {$[106]$} \\
\hline 54. & Salvia splenden & Lamiaceae & & & Not specified & Hypoglycemic activity & [106] \\
\hline 55. & Salvia tillifolia & Lamiaceae & & Aerial part & $\begin{array}{l}\text { Methanolic extract of } \\
\text { aerial part }\end{array}$ & $\begin{array}{l}\text { Hypoglycemic activity, } \\
\text { headache, stomach trouble } \\
\text { and as memory enhancing } \\
\text { herb }\end{array}$ & {$[106]$} \\
\hline 56. & Ricinus communis & Euphorbiaceae & Gulo (A) & Roots & Not specified & anti-diabetic & [81] \\
\hline 57. & $\begin{array}{l}\text { Securidaca } \\
\text { longepedunculata } \\
\text { Fresen }\end{array}$ & Polygalaceae) & & root bark & $\begin{array}{l}\text { Malaria, rheumatism, } \\
\text { gonorrhea, palpitations, } \\
\text { pneumonia, syphilis, } \\
\text { asthma }\end{array}$ & $\begin{array}{l}\text { diabetes, inflammation, } \\
\text { insanity and epilepsy, } \\
\text { wounds, cough, venereal } \\
\text { diseases, snake bite etc }\end{array}$ & {$[107,108]$} \\
\hline 58. & Balanites rotundifolia & Balanitaceae & Alayto (Sm) & Leaves & $\begin{array}{l}\text { Soaking crushed fresh } \\
\text { leaves in water and the } \\
\text { water is taken orally }\end{array}$ & Laxative, fevers, diabetes & [109] \\
\hline 59. & $\begin{array}{l}\text { Buxus hildebrandtii } \\
\text { Baill. }\end{array}$ & Buxaceae & Gaydarto & Leaves & $\begin{array}{l}\text { Soaking crushed fresh } \\
\text { leaves in water and the } \\
\text { water is taken orally }\end{array}$ & $\begin{array}{l}\text { Diabetes, infections, } \\
\text { parasites }\end{array}$ & [109] \\
\hline 60. & $\begin{array}{l}\text { Lavandula } \\
\text { coronopifolia L. }\end{array}$ & Lamiaceae & Dananwada (Sm) & $\begin{array}{l}\text { Plant parts } \\
\text { without } \\
\text { leaves }\end{array}$ & $\begin{array}{l}\text { Soaking crushed plants } \\
\text { without the leaves in } \\
\text { water and the water is } \\
\text { taken orally }\end{array}$ & $\begin{array}{l}\text { Diabetes, sun burns, } \\
\text { Kidney problems, side ache } \\
\text { problems }\end{array}$ & {$[109]$} \\
\hline 61. & Melia azedarach $L$. & Meliaceae & Dat caxa (Sm) & Whole plant & $\begin{array}{l}\text { Soaking crushed whole } \\
\text { plant in water and the } \\
\text { water is taken orally }\end{array}$ & Diabetes, Wound infections & [109] \\
\hline 62. & $\begin{array}{l}\text { Nepeta azurea R.Br. Ex } \\
\text { Benth. }\end{array}$ & Lamiaceae & Simitri (Sm) & Leaves & $\begin{array}{l}\text { Soaking crushed leaves } \\
\text { in boiled water and the } \\
\text { water is taken orally }\end{array}$ & $\begin{array}{l}\text { Diabetes ,kidney diseases, } \\
\text { asthma }\end{array}$ & [109] \\
\hline 63. & $\begin{array}{l}\text { Tarchonanthus thiopias } \\
\text { L. }\end{array}$ & Asteraceae & Galqaddo (Sm) & & $\begin{array}{l}\text { Soaking crushed leaves } \\
\text { in water for } 1 \mathrm{~h} \text { and the } \\
\text { water is taken orally }\end{array}$ & $\begin{array}{l}\text { Diabetes, Bladder } \\
\text { inflammations }\end{array}$ & [109] \\
\hline 64. & Cinnamomumverum & Lauraceae & & & Not specified & Diabetes & [110] \\
\hline 65. & $\begin{array}{l}\text { Azadirachta indica A. } \\
\text { Juss. }\end{array}$ & Meliaceae & Neem $(T)$ & $\begin{array}{l}\text { leaf, stem } \\
\text { bark }\end{array}$ & $\begin{array}{l}\text { Leaf or bark decoction } \\
\text { used for drinking }\end{array}$ & $\begin{array}{l}\text { Insect repellent, malaria, } \\
\text { skin diseases, anthelmintic, } \\
\text { diuretic }\end{array}$ & {$[73,110]$} \\
\hline 66. & Aloe megalacantha & Asphodeloideae & & & Not specified & Diabetes & {$[110]$} \\
\hline 67. & Justicia Schimperiana & Acantanceae & & Leaves & Not specified & Diabetes & [54] \\
\hline 68. & $\begin{array}{l}\text { Lysimachia ruhmeriana } \\
\text { vatke }\end{array}$ & primulaceae & & & Not specified & Diabetes, haemorrhoids & [43] \\
\hline 69. & $\begin{array}{l}\text { Thymus serrulatus } \\
\text { Hochst ex Benth, }\end{array}$ & Labiatae & & & Not specified & $\begin{array}{l}\text { Diabetes, hypertension, } \\
\text { rheumatism, menorrhagia, } \\
\text { amenorrhoea }\end{array}$ & [43] \\
\hline
\end{tabular}




\begin{tabular}{|c|c|c|c|c|c|c|c|}
\hline 70. & $\begin{array}{l}\text { Verbascum sinaiticum } \\
\text { Benth. }\end{array}$ & Scrophulariaceae & & & Not specified & $\begin{array}{l}\text { Diabetes, scabies, colic, } \\
\text { anti-emetic, amoebiasis, } \\
\text { diarrhoea, epilepsy, } \\
\text { aphrodisiac, infertility }\end{array}$ & {$[43]$} \\
\hline 71. & Verbena officinalis $L$ & Verbenaceae & & & Not specified & $\begin{array}{l}\text { Anti-emetic, malaria, } \\
\text { diabetes, burns, respiratory } \\
\text { diseases }\end{array}$ & [43] \\
\hline 72. & Rubus steudneri & Rubiaceae & Enjori (A) & Leaf & Not specified & $\begin{array}{l}\text { Liver disorders, diabetes, } \\
\text { cough, gum pain, anti- } \\
\text { oxidant }\end{array}$ & [43] \\
\hline 73. & Arachis hypogeal l. & Leguminaseae & & flower & $\begin{array}{l}\text { In prepared foodstuffs } \\
\text { such as biscuits and } \\
\text { sweetmeats }\end{array}$ & Diabetes & [43] \\
\hline 74. & Coffea Arabica L. & Rubiaceae & Buna $[\mathrm{A}]$ & Green seed & Not specified & $\begin{array}{l}\text { Blood glucose level } \\
\text { decreased in mice after } \\
\text { oral administration of the } \\
\text { substance }\end{array}$ & [43] \\
\hline 75. & $\begin{array}{l}\text { Cucurma domestic } \\
\text { valeton }\end{array}$ & zingibraceae & & Rhizome & Not specified & $\begin{array}{l}\text { Reduces or helps to control } \\
\text { blood sugar }\end{array}$ & [43] \\
\hline 76. & morus spp & Moraceae & & & Not specified & $\begin{array}{l}\text { Shows anti-hyperglycemic } \\
\text { activity in vivo. }\end{array}$ & [43] \\
\hline 77. & Ammi visnaga (L.) Lam. & Apiacea & E'bna $(T)$ & leaf & $\begin{array}{l}\text { Leaf extract is used in } \\
\text { the morning }\end{array}$ & $\begin{array}{l}\text { Diabetes ,diuretic, } \\
\text { hypotensive, hair-care, } \\
\text { antispasmodic, asthma }\end{array}$ & [73] \\
\hline 78. & $\begin{array}{l}\text { Anethum graveolens } \\
\text { Linn }\end{array}$ & Apiacea & Shilan-maedo (T) & leaf & $\begin{array}{l}\text { Tea of the leaves is } \\
\text { taken twice daily }\end{array}$ & $\begin{array}{l}\text { Diabetes, diarrhea, eye } \\
\text { problems, indigestion, } \\
\text { stomachache }\end{array}$ & [73] \\
\hline 79. & $\begin{array}{l}\text { Balanites aegyptica } \\
\text { (L.) Del. }\end{array}$ & Balanitaceae & Mekie (T) & leaf, fruit & $\begin{array}{l}\text { Leaf extract or ripe fruit } \\
\text { is taken }\end{array}$ & $\begin{array}{l}\text { Purgative, insecticidal, } \\
\text { laxative, stomach aches }\end{array}$ & [73] \\
\hline 80. & Brassica nigra Koch. & Brassicaceae & Adri (T) & Seed & $\begin{array}{l}\text { Seed decoction is used } \\
\text { regularly }\end{array}$ & $\begin{array}{l}\text { Gastrointestinal disorder, } \\
\text { stimulant, diuretic, } \\
\text { bronchitis }\end{array}$ & [73] \\
\hline 81. & $\begin{array}{l}\text { Calotropis procera } \\
\text { (Ait.) }\end{array}$ & Asclepiadaceae & Ghinde'a (T) & $\begin{array}{l}\text { stem bark, } \\
\text { latex }\end{array}$ & $\begin{array}{l}\text { Crushed bark or latex } \\
\text { are mixed with butter }\end{array}$ & $\begin{array}{l}\text { Skin diseases, anthelmintic, } \\
\text { expectorant, wounds, } \\
\text { diarrhea }\end{array}$ & [73] \\
\hline 82. & $\begin{array}{l}\text { Capparis thiopia } \\
\text { (Forssk.) }\end{array}$ & Caparidiacea & Sorob $[\mathrm{T}]$ & $\begin{array}{l}\text { stem bark, } \\
\text { leaf }\end{array}$ & $\begin{array}{l}\text { Infusion of stem bark or } \\
\text { leaf is used }\end{array}$ & $\begin{array}{l}\text { Tooth ache, cough, } \\
\text { arthritis, anthelmintic, } \\
\text { malaria, inflammation }\end{array}$ & [73] \\
\hline 83. & Carica papaya $L$. & Caricaceae & Papaya (T) & leaf, seed & $\begin{array}{l}\text { Decoction of seed or } \\
\text { leaf is drunk } 1 \text { beaker in } \\
\text { the morning }\end{array}$ & $\begin{array}{l}\text { Amoebicide, hypertension, } \\
\text { constipation, expel worms, } \\
\text { laxative, Hypoglycemic } \\
\text { and Antihyperglycemic } \\
\text { effects }\end{array}$ & {$[73,87]$} \\
\hline 84. & Carissa edulis (Forssk) & Apocynaceae & $\operatorname{Agam}(\mathrm{T})$ & stem bark & $\begin{array}{l}\text { Extract of stem bark is } \\
\text { drunk regularly }\end{array}$ & $\begin{array}{l}\text { Anthelmintic, } \\
\text { inflammation, hypotensive, } \\
\text { diuretics, headache }\end{array}$ & [73] \\
\hline 85. & Cichorium endivia $L$. & Asteraceae & Shikoria $(\mathrm{T})$ & Leaf & $\begin{array}{l}\text { Cooked properly and } \\
\text { eaten with enjera }\end{array}$ & $\begin{array}{l}\text { Appetizer, febrifuge, anti- } \\
\text { allergic }\end{array}$ & [73] \\
\hline 86. & $\begin{array}{l}\text { Clerodendrum } \\
\text { myricoides (Hochst) }\end{array}$ & Lamiaceae & $\begin{array}{l}\text { Sur-betri / } \\
\text { Ugandense (T) }\end{array}$ & $\begin{array}{l}\text { stem bark, } \\
\text { leaf }\end{array}$ & $\begin{array}{l}\text { Leaf or stem bark } \\
\text { extract is drunk } \\
\text { regularly }\end{array}$ & $\begin{array}{l}\text { Abdominal pains, snake } \\
\text { bites, hemorrhoids, eye } \\
\text { disease }\end{array}$ & [73] \\
\hline 87. & $\begin{array}{l}\text { Clutia lanceolata } \\
\text { (Forssk) }\end{array}$ & Euphorbiaceae & Tish-belalito (T) / & Leaf & $\begin{array}{l}\text { Leaf extract is taken } \\
\text { twice a day }\end{array}$ & $\begin{array}{l}\text { Malaria, diarrhea, colds, } \\
\text { gynecological problems }\end{array}$ & [73] \\
\hline 88. & Daucus carota L. & Apiacea & Caroti (T) & tuber & $\begin{array}{l}\text { Tuber is eaten in raw or } \\
\text { with salad }\end{array}$ & $\begin{array}{l}\text { Diuretic, inflammation, } \\
\text { leprosy, worms troubles }\end{array}$ & [73] \\
\hline 89. & $\begin{array}{l}\text { Entada abyssinica } \\
\text { Steud. Ex A. }\end{array}$ & Fabaceae & Halke (T) & $\begin{array}{l}\text { stem bark, } \\
\text { leaf }\end{array}$ & $\begin{array}{l}\text { Decoction of the stem } \\
\text { bark or leaf }\end{array}$ & $\begin{array}{l}\text { Gastrointestinal problems, } \\
\text { cold, candidiasis }\end{array}$ & [73] \\
\hline 90. & $\begin{array}{l}\text { Eucalptus thiopia } \\
\text { (Labill.) }\end{array}$ & Myrtaceae & $\begin{array}{l}\text { Tsaeda- } \\
\text { kelamintos(T) }\end{array}$ & Leaf & $\begin{array}{l}\text { Leaf extract is taken } 1 \\
\text { cup per day }\end{array}$ & $\begin{array}{l}\text { Insect repellent, } \\
\text { tuberculosis, bronchitis, } \\
\text { malaria, skin diseases }\end{array}$ & [73] \\
\hline 91. & Ferula communis $L$. & Apiacea & $\operatorname{Diog}(\mathrm{T})$ & seed, leaf & $\begin{array}{l}\text { Decoction of fresh leaf } \\
\text { or dried seed }\end{array}$ & $\begin{array}{l}\text { Antispasmodic, diarrhea, } \\
\text { expectorant ,dermatitis }\end{array}$ & [73] \\
\hline 92. & $\begin{array}{l}\text { Gymnema sylvestre } \\
\text { Roxb. }\end{array}$ & Asclepiadaceae & Shankuk (T) & Leaf & Leaf extract is taken & $\begin{array}{l}\text { daily Cough, } \\
\text { inflammations, } \\
\text { constipation, haemorrhoids, } \\
\text { bronchitis }\end{array}$ & [73] \\
\hline 93. & $\begin{array}{l}\text { Kigelia thiopia (Lam.) } \\
\text { Benth. }\end{array}$ & Bignoniaceae & $\begin{array}{l}\text { Mederba/Zelzale } \\
\text { (T) }\end{array}$ & Fruit & Fruits are eaten & $\begin{array}{l}\text { Constipation, tapeworm, } \\
\text { dysentery, gynecological } \\
\text { disorders }\end{array}$ & [73] \\
\hline
\end{tabular}




\begin{tabular}{|c|c|c|c|c|c|c|c|}
\hline 94. & Lepidium sativum L. & Brassicaceae & Shinfae (T) & Seed & $\begin{array}{l}\text { The seed extract is } \\
\text { taken before bed }\end{array}$ & $\begin{array}{l}\text { Diuretic, cough, laxative, } \\
\text { asthma, diarrhea, malaria, } \\
\text { hypoglycemic effects }\end{array}$ & {$[43,73]$} \\
\hline 95. & Moringa oleifera Lam. & Moringaceae & Moringa $(\mathrm{T}) /$ & Leaf & $\begin{array}{l}\text { Fresh leaf juice taken } \\
\text { every morning in empty } \\
\text { stomach }\end{array}$ & $\begin{array}{l}\text { Asthma, constipation, skin } \\
\text { diseases, diarrhea, stomach } \\
\text { pain, hypertension }\end{array}$ & [73] \\
\hline 96. & Plumbago zeylanica $L$. & Plumbaginaceae & Aftooh (T) & root, stem & $\begin{array}{l}\text { Decoction of stem or } \\
\text { roots used trice a day }\end{array}$ & $\begin{array}{l}\text { Stimulant, abortifacient, } \\
\text { inflammation, bronchitis, } \\
\text { itching }\end{array}$ & [73] \\
\hline 97. & $\begin{array}{l}\text { Psiada panctulata } \\
\text { (DC.) Vatke - }\end{array}$ & Asteraceae & Tsehaiferhet (T) & leaf, root & $\begin{array}{l}\text { Decoction of the leaves } \\
\text { or roots is used }\end{array}$ & $\begin{array}{l}\text { Cough, anti-abortion, } \\
\text { asthma }\end{array}$ & [73] \\
\hline 98. & $\begin{array}{l}\text { Rosmarius officianilis } \\
\text { L. }\end{array}$ & Lamiaceae & Azmarino $(\mathrm{T})$ y & Leaf, stem & $\begin{array}{l}\text { A spoon of leaf or stem } \\
\text { is added in daily food }\end{array}$ & $\begin{array}{l}\text { Stomach pains, } \\
\text { gynecological problems, } \\
\text { bad breath, migraine }\end{array}$ & [73] \\
\hline 99. & $\begin{array}{l}\text { Steganotaenia } \\
\text { araliacea Hochst. }\end{array}$ & Apiaceae & $\begin{array}{l}\text { Mewets denagl } \\
\text { (T) }\end{array}$ & leaf, seed & $\begin{array}{l}\text { Decoction of either leaf } \\
\text { or seed mixed with milk } \\
\text { is taken in the morning }\end{array}$ & $\begin{array}{l}\text { Sore-throat, ulcer, diuretic, } \\
\text { stomachache, dysentery, } \\
\text { hypotensive }\end{array}$ & [73] \\
\hline 100. & Tamarindus indica L. $t$ & Fabaceae & Humer (T) & fruit & $\begin{array}{l}\text { Extract of the fruit is } \\
\text { taken twice a day }\end{array}$ & $\begin{array}{l}\text { Malaria, fever, stomach } \\
\text { ache, wounds, purgative }\end{array}$ & [73] \\
\hline 101. & $\begin{array}{l}\text { Terminalia thiopi } \\
\text { Fresen }\end{array}$ & Combretaceae & weiba (T) & $\begin{array}{l}\text { stem bark, } \\
\text { leaf }\end{array}$ & $\begin{array}{l}\text { Decoction of the stem } \\
\text { bark or leaf }\end{array}$ & $\begin{array}{l}\text { Wounds, malaria, } \\
\text { dermatitis, tuberculosis }\end{array}$ & [73] \\
\hline 102. & $\begin{array}{l}\text { Trachyspermum ammi } \\
\text { (L.) }\end{array}$ & Apiaceae & $\begin{array}{l}\text { Kamun/Tsakida } \\
\text { (T) }\end{array}$ & Seed & $\begin{array}{l}\text { Seed powder is soaked } \\
\text { in water or milk }\end{array}$ & $\begin{array}{l}\text { Hypertension, diarrhea, } \\
\text { asthma, anti-helminthic, } \\
\text { diuretic }\end{array}$ & [73] \\
\hline 103. & $\begin{array}{l}\text { Vernonia amygdalina } \\
\text { Del. }\end{array}$ & Asteraceae & Grawa $(\mathrm{T})$ & $\begin{array}{l}\text { leaf, stem } \\
\text { bark }\end{array}$ & $\begin{array}{l}\text { The extract of fresh } \\
\text { leaves in water is used }\end{array}$ & $\begin{array}{l}\text { Stomach ache, skin } \\
\text { infections, tooth ache, } \\
\text { cough, malaria, }\end{array}$ & [73] \\
\hline 104. & Withania somnifera (L.) & Solanaceae & Agol (T) & root, leaf & $\begin{array}{l}\text { Roots are immersed in } \\
\text { hot water and the juice } \\
\text { of the leaves }\end{array}$ & $\begin{array}{l}\text { Diabetes, constipation, skin } \\
\text { infection, rheumatism }\end{array}$ & [73] \\
\hline 105. & $\begin{array}{l}\text { Zizyphus spina-christi } \\
\text { (L.) }\end{array}$ & Rhamnaceae & Gaba (T) & Leaf & $\begin{array}{l}\text { Infusion of the leaves } \\
\text { used regularly }\end{array}$ & $\begin{array}{l}\text { Diarrhea, dandruff, skin } \\
\text { infections, bronchitis, } \\
\text { malaria }\end{array}$ & [73] \\
\hline
\end{tabular}

$[\mathrm{A}]=$ Amharic, $[\mathrm{O}]=$ Affan Oromo, $[\mathrm{T}]=$ Tigrigna, $[\mathrm{Sm}]=$ Somaligna, $[\mathrm{Sd}]=$ Sidamigna

Table 2. List of medcinal plants in terms of citation

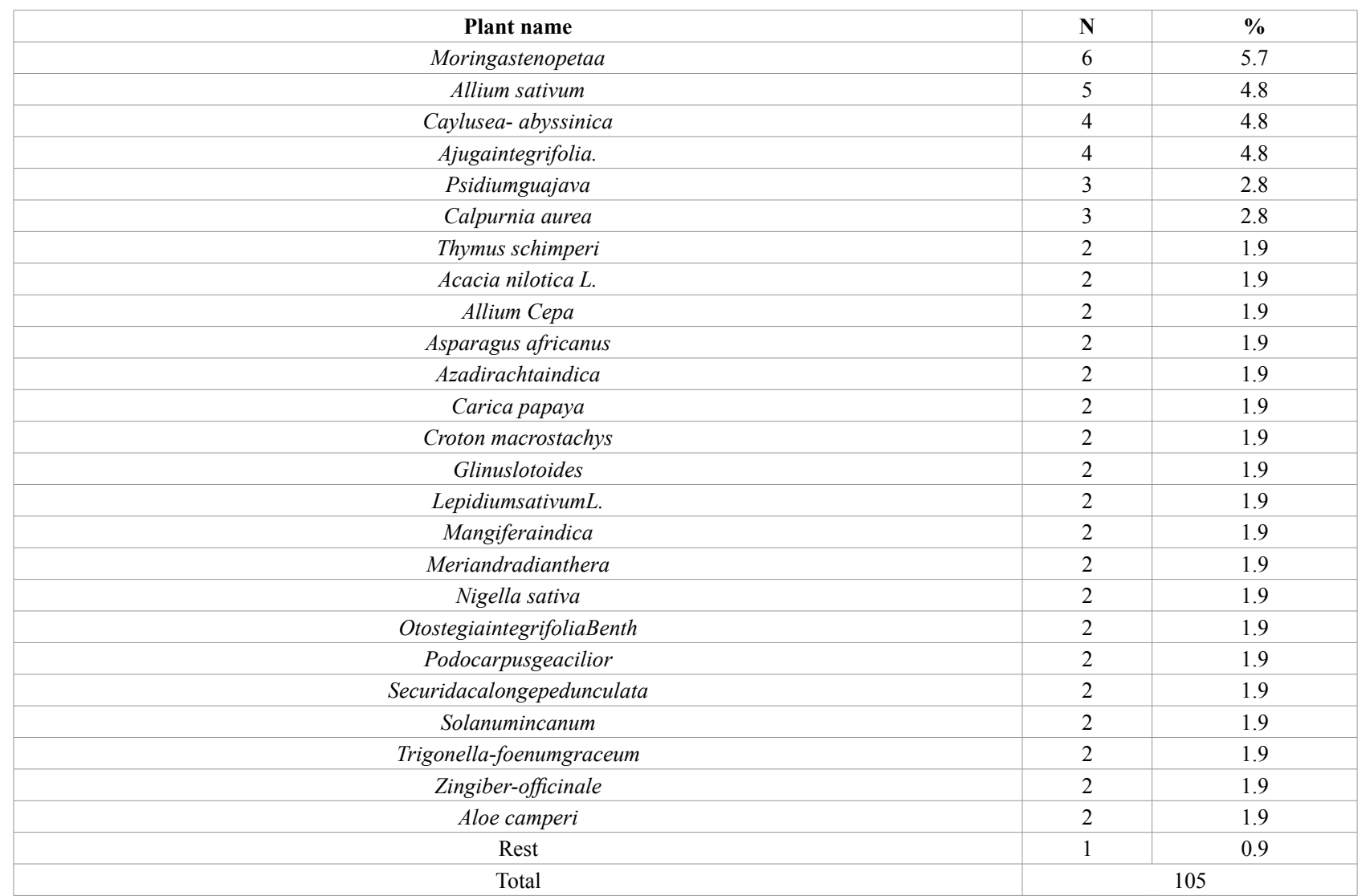




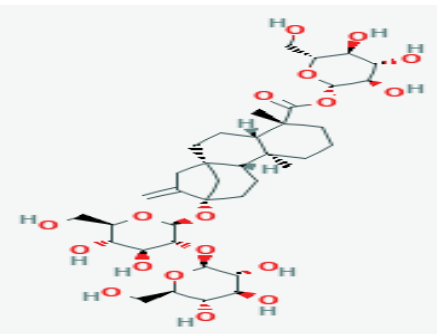

Stevioside

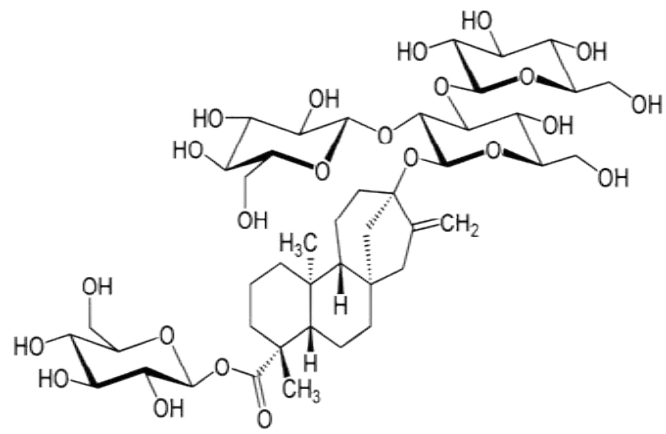

Rebaudioside A

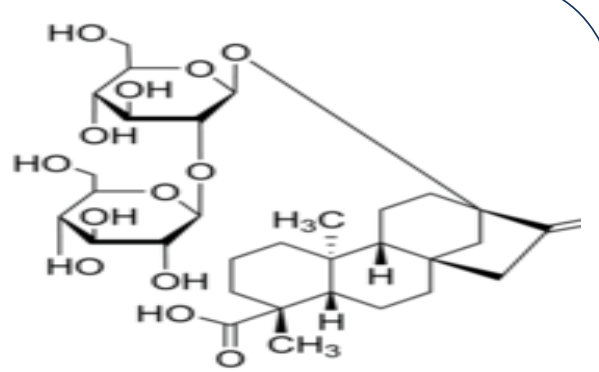

Steviolbioside

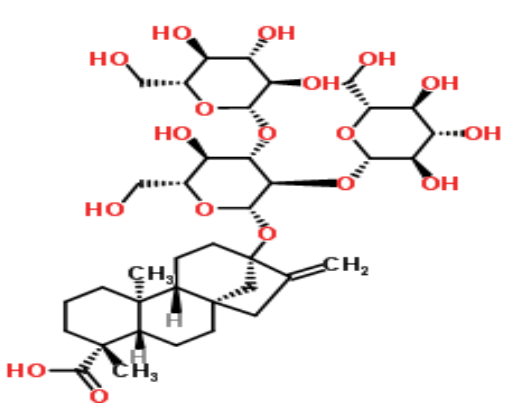

Rebaudioside B

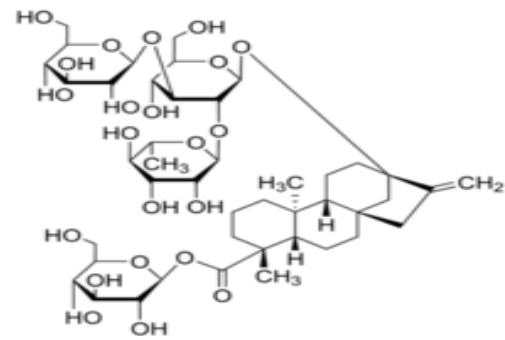

Rebaudioside C

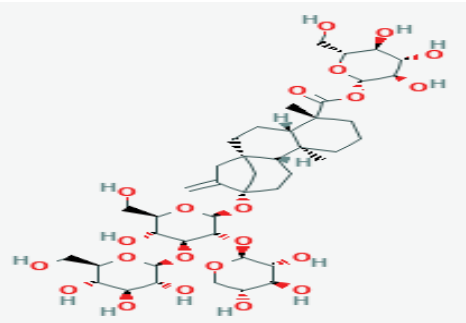

Rebaudioside F

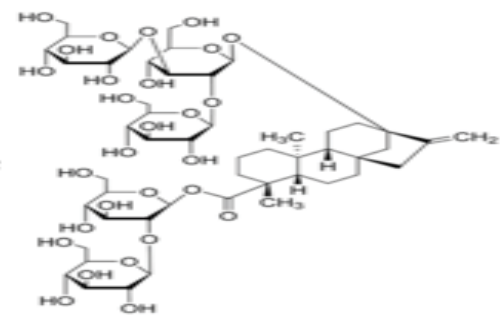

Rebaudioside D

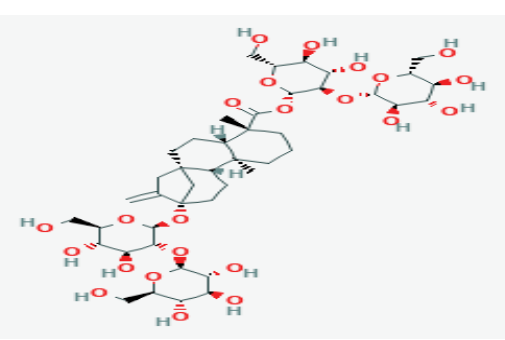

Rebaudioside E

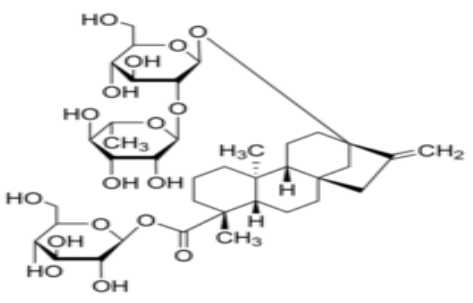

Ducloside A

Figure 1. Structures of diterpene glycosides 


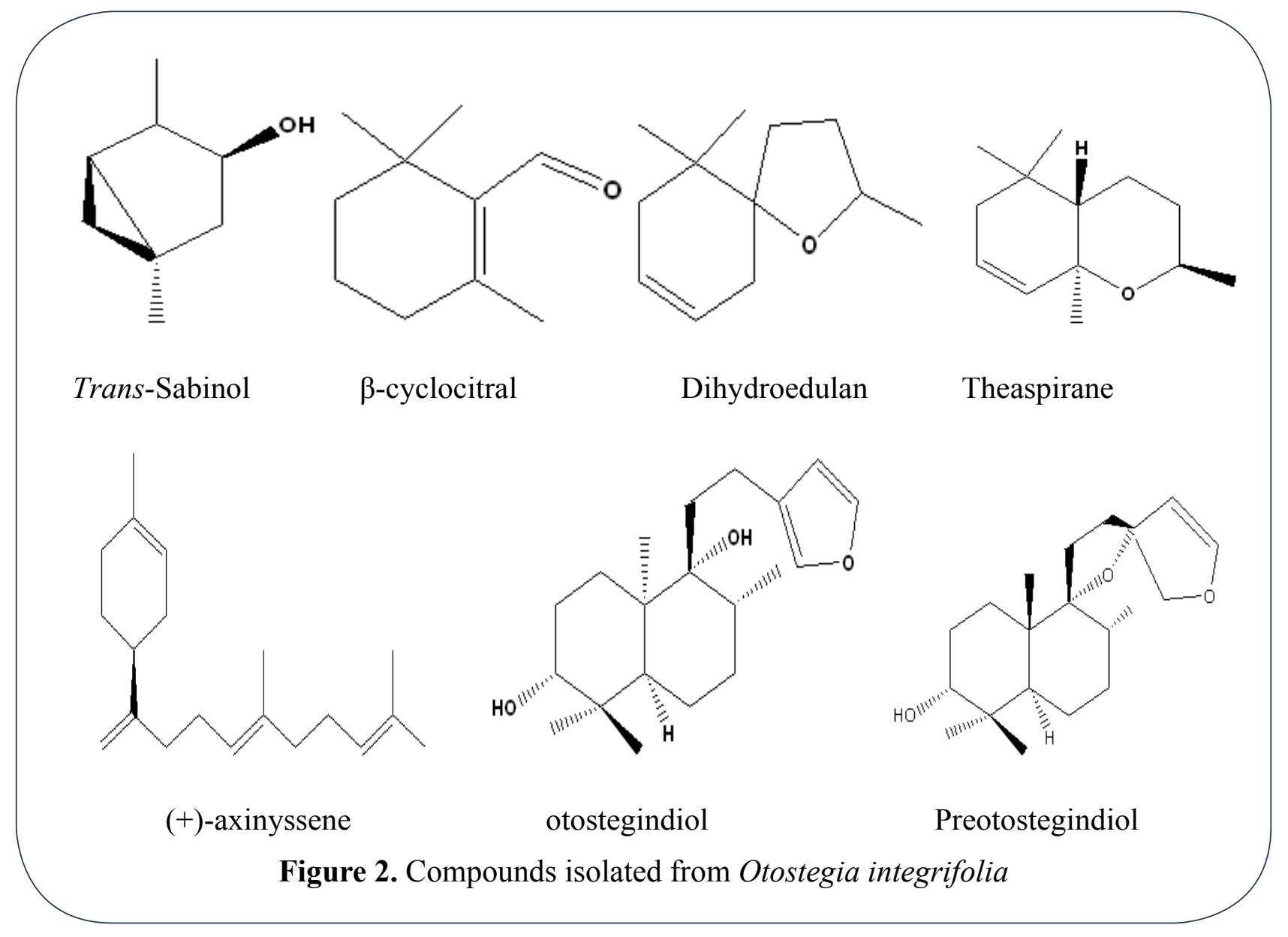




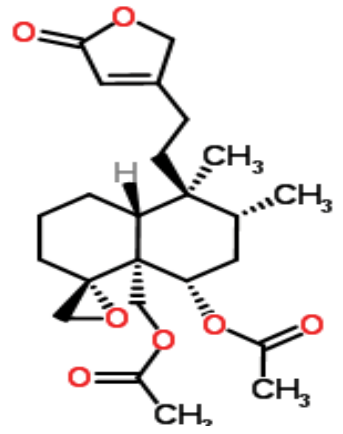

Ajugarin I

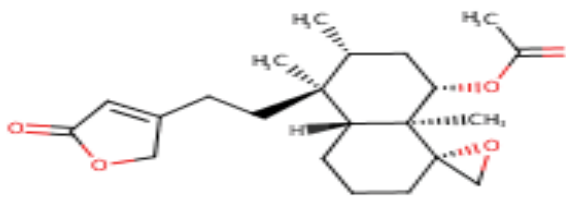

Ajugarin V

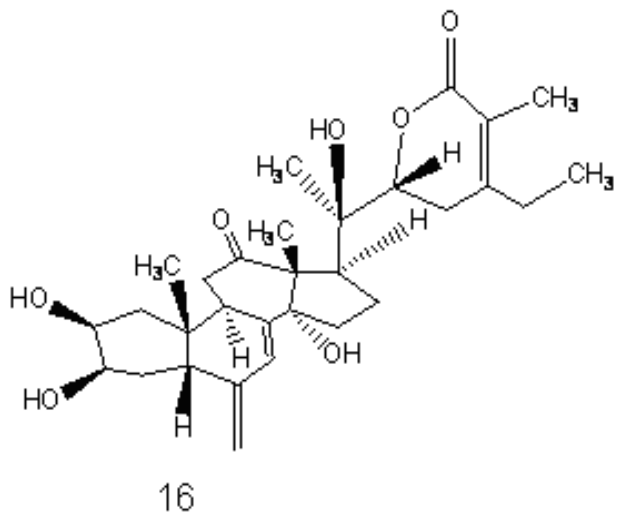

Ajugalactone

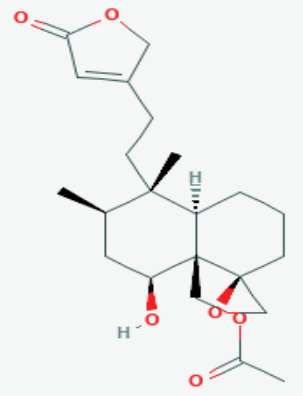

Ajugarin II

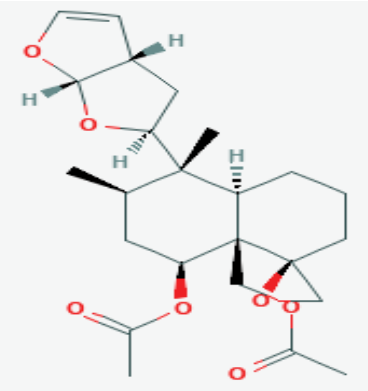

clerodin

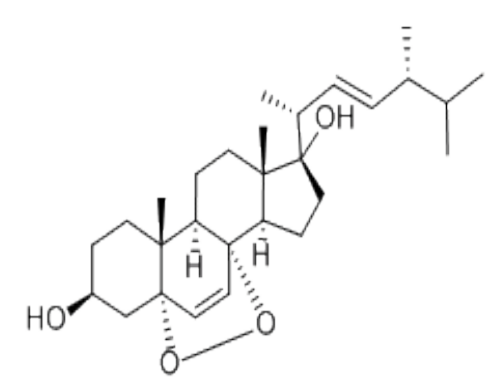

Ergosterol-5, 8-endoperoxide

Figure 3. Compounds isolated from Ajuga remota Benth 


\section{WWWWWWW}

Pentatriacontane

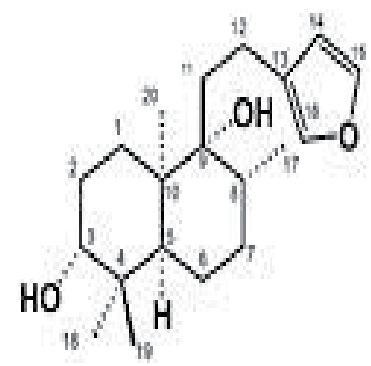

Otostegindiol

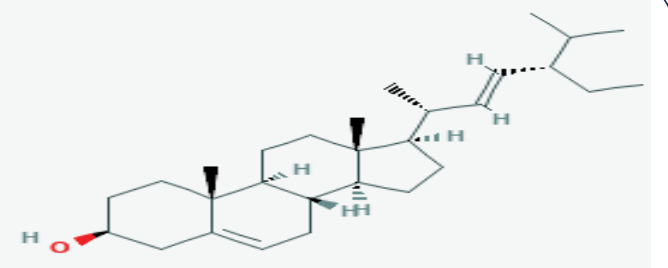

Stigmasterol

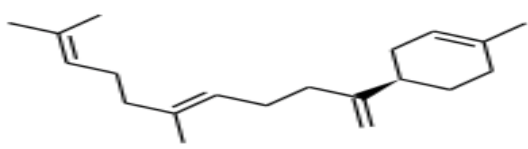

Figure 4. Some isolated compounds of Otostegia integrifolia Benth

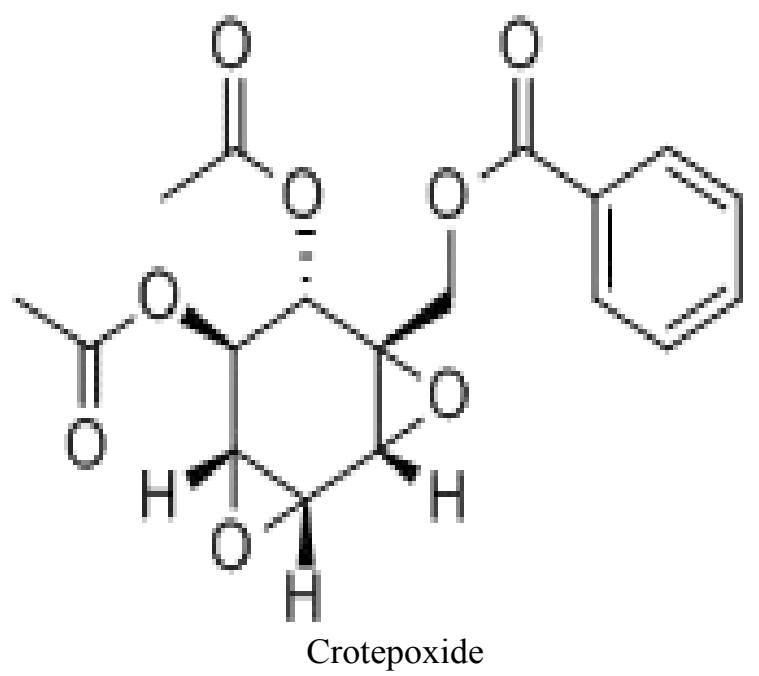

Figure 5. Some isolated compounds of Croton macrostachys 


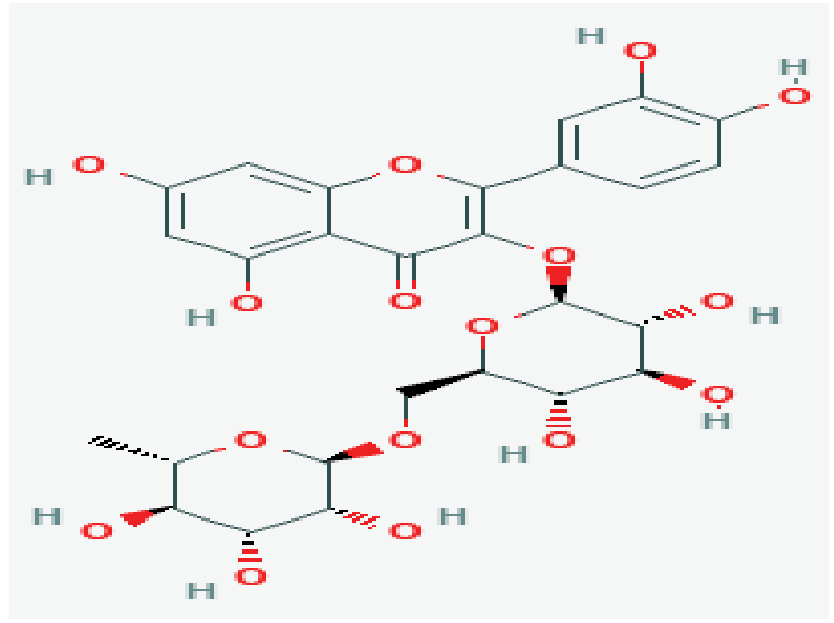

Figure 6. Chemical structure of Rutin

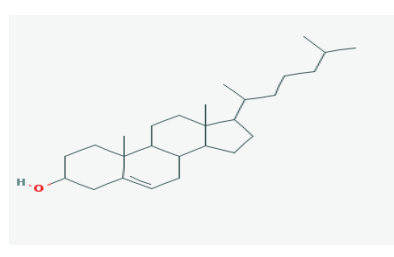

cholest-5-en-3-ol

Palmitic acid

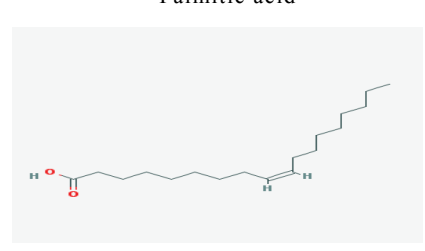

n-octacosane

Oleic acid

Figure 7. Some of the isolated compounds of Moringa stenopetala

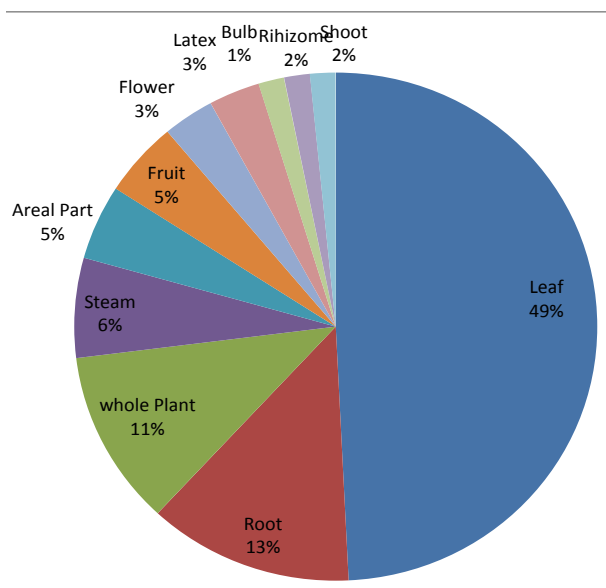

Figure 8. Medicinal plant parts used for the management of diabetics in Ethiopia 